\title{
A Systematic Review and Meta-Analysis of the In Vivo Haemodynamic Effects of $\Delta^{9}$-Tetrahydrocannabinol
}

\author{
Salahaden R. Sultan ${ }^{1,2}$, Sophie A. Millar ${ }^{1}{ }^{(\mathbb{D}}$, Saoirse E. $\mathrm{O}^{\prime}$ Sullivan ${ }^{1}$ and \\ Timothy J. England 1,* (1) \\ 1 Division of Medical Sciences \& Graduate Entry Medicine, School of Medicine, University of Nottingham, \\ Derby DE22 3DT, UK; mzxss4@nottingham.ac.uk (S.R.S.); stxsamil@nottingham.ac.uk (S.A.M.); \\ mbzso@nottingham.ac.uk (S.E.O.) \\ 2 Faculty of Applied Medical Sciences, King Abdulaziz University, Jeddah 21589, Saudi Arabia \\ * Correspondence: timothy.england@nottingham.ac.uk; Tel.: +44-1332-724668
}

Received: 4 December 2017; Accepted: 26 January 2018; Published: 31 January 2018

\begin{abstract}
Delta^{9}$-Tetrahydrocannabinol (THC) has complex effects on the cardiovascular system. We aimed to systematically review studies of THC and haemodynamic alterations. PubMed, Medline, and EMBASE were searched for relevant studies. Changes in blood pressure (BP), heart rate (HR), and blood flow (BF) were analysed using the Cochrane Review Manager Software. Thirty-one studies met the eligibility criteria. Fourteen publications assessed BP (number, $n=541), 22 \mathrm{HR}(n=567)$, and $3 \mathrm{BF}(n=45)$. Acute THC dosing reduced BP and HR in anaesthetised animals (BP, mean difference (MD) $-19.7 \mathrm{mmHg}, p<0.00001$; HR, MD $-53.49 \mathrm{bpm}, p<0.00001)$, conscious animals (BP, MD - 12.3 mmHg, $p=0.0007 ; \mathrm{HR}, \mathrm{MD}-30.05 \mathrm{bpm}, p<0.00001$ ), and animal models of stress or hypertension (BP, MD $-61.37 \mathrm{mmHg}, p=0.03$ ) and increased cerebral $\mathrm{BF}$ in murine stroke models (MD 32.35\%, $p<0.00001)$. Chronic dosing increased BF in large arteries in anaesthetised animals (MD $21.95 \mathrm{~mL} / \mathrm{min}, p=0.05$ ) and reduced BP in models of stress or hypertension (MD $-22.09 \mathrm{mmHg}$, $p<0.00001$ ). In humans, acute administration increased HR (MD $8.16 \mathrm{bpm}, p<0.00001$ ). THC acts differently according to species and experimental conditions, causing bradycardia, hypotension and increased BF in animals; and causing increased HR in humans. Data is limited, and further studies assessing THC-induced haemodynamic changes in humans should be considered.
\end{abstract}

Keywords: $\Delta^{9}$-Tetrahydrocannabinol; THC; cardiovascular system; blood pressure; heart rate; blood flow

\section{Introduction}

$\Delta^{9}$-Tetrahydrocannabinol (THC) is the most abundant and widely studied phytocannabinoid, first discovered in 1964 [1]. THC is a partial agonist of both cannabinoid receptors $\mathrm{CB}_{1}$ and $\mathrm{CB}_{2}$ and other targets including $G$ protein-coupled receptors GPR55 and GPR18 [2-4]. THC possesses interesting therapeutic potential as an antiemetic, appetite stimulant, and analgesic, and for the treatment of glaucoma, epilepsy, Parkinson's disease, and multiple sclerosis [5-7]. THC has been shown to be effective against refractory nausea and vomiting in cancer patients undergoing chemotherapy [8]. However, its use as a therapeutic agent is limited by its recognised psychogenic side effects including hallucinations, euphoria, dizziness, mood changes, nausea, and fatigue [8-10].

THC has numerous cardiovascular effects in animals and humans. In vitro studies have shown that THC causes endothelium-independent vasorelaxation of rabbit superior mesenteric arteries [11] and vasorelaxation of the rat mesenteric artery through sensory nerves via a $C_{1}$ and $\mathrm{CB}_{2}$ receptor-independent mechanism [12]. Other studies have found THC to activate a $G$ 
protein-coupled receptor, inhibit calcium channels, and activate potassium channels in the rat mesenteric vasculature [13] and to cause endothelium-dependent and time-dependent vasorelaxation in the rat aorta $[14,15]$. In contrast, other studies have shown that THC causes vasoconstriction in guinea pig pulmonary arteries [16], rat mesenteric arteries and aorta [14,17], and rabbit ear arteries [18].

In vivo studies have reported different haemodynamic responses post-THC. An acute administration of THC caused hypotension and bradycardia in anesthetised dogs (intravenously; i.v.), conscious bats (intraperitoneal; i.p.), and humans (oral) [19-21]. In contrast, tachycardia and hypertension were reported in rats after i.p. administration of THC [22,23]. More complex effects on BP were induced by THC in anaesthetised rats [24]. The available evidence to date suggests that THC alters the haemodynamics in animals and humans, albeit with conflicting results variable with species, route of administration, and experimental conditions. Therefore, the aim this study was to systematically review and meta-analyse the in vivo literature assessing the effects of THC on the cardiovascular system in all species under different conditions.

\section{Results}

From the initial 2743 search results, 1935 relevant publications were identified and evaluated from three databases (Medline, EMBASE, and PubMed). Of these, 30 articles met the inclusion criteria and 1 article was added manually (Figure 1). A summary of the data extracted from the included studies is shown in Table 1.

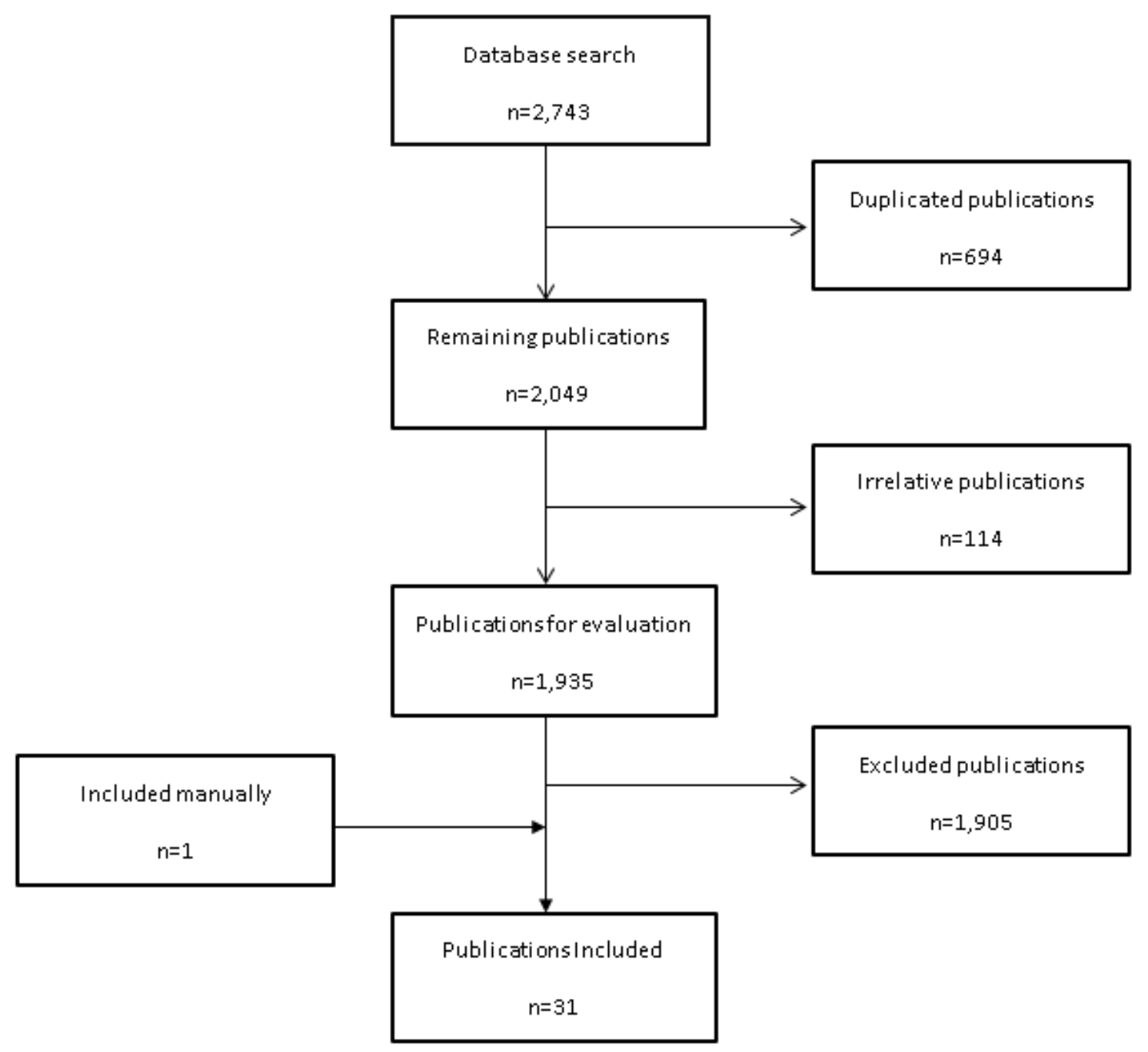

Figure 1. Flow chart for study retrieval and selection. 
Table 1. Summary of the included studies divided according to the experimental conditions.

\begin{tabular}{|c|c|c|c|c|c|c|c|c|c|}
\hline $\begin{array}{c}\text { Author \& } \\
\text { Year }\end{array}$ & Study Description & $\begin{array}{c}\text { Species, Model } \\
\text { (Anaesthetic \& Route) }\end{array}$ & Sample Size & THC Dose & THC Route & $\begin{array}{c}\text { Time of THC } \\
\text { Administration }\end{array}$ & $\begin{array}{c}\text { Time of Haemodynamic } \\
\text { Measurements }\end{array}$ & $\begin{array}{c}\text { Basal } \\
\text { Parameters * }\end{array}$ & Outcomes and Comments \\
\hline \multicolumn{10}{|c|}{ Anaesthetised animals } \\
\hline $\begin{array}{l}\text { Cavero } \\
1972[25]\end{array}$ & $\begin{array}{l}\text { Investigate the } \\
\text { haemodynamic } \\
\text { effects of THC }\end{array}$ & $\begin{array}{l}\text { Dogs Anaesthetised } \\
\text { (pentobarbital, iv) }\end{array}$ & 11 & $2.5 \mathrm{mg} / \mathrm{kg}$ & i.v. & Post-anaesthesia & $\begin{array}{l}\text { Continues for } 30 \mathrm{~m} \\
\text { post-drug }\end{array}$ & - & $\begin{array}{l}\text { THC altered distribution of } \\
\text { regional BF, and reduced HR } \\
\text { and BP. }\end{array}$ \\
\hline $\begin{array}{l}\text { Cavero } \\
\text { 1973a [26] }\end{array}$ & $\begin{array}{l}\text { Investigate the } \\
\text { haemodynamic } \\
\text { effects of THC }\end{array}$ & $\begin{array}{l}\text { Dogs Anaesthetised } \\
\text { (pentobarbital, iv) }\end{array}$ & 23 & $39 \mu \mathrm{\mu g} / \mathrm{kg}-2.5 \mathrm{mg} / \mathrm{kg}$ & i.v. & Post-anaesthesia & $\begin{array}{l}\text { Continues for } 2 \mathrm{~h} \\
\text { post-drug }\end{array}$ & $\begin{array}{l}\text { C: HR:169, } \\
\text { BP:91.7; T: } \\
\text { HR:165.7, } \\
\text { BP:93.5 }\end{array}$ & $\begin{array}{c}\text { THC caused reduction in HR } \\
\text { and BP mediated via central } \\
\text { nervous system. }\end{array}$ \\
\hline $\begin{array}{c}\text { Cavero } \\
1973 b[27]\end{array}$ & $\begin{array}{l}\text { Characterise the } \\
\text { mechanism of } \\
\text { action of THC } \\
\text { on HR }\end{array}$ & $\begin{array}{l}\text { Dogs Anaesthetised } \\
\text { (pentobarbital, iv) }\end{array}$ & 29 & $39 \mu \mathrm{g} / \mathrm{kg}-5 \mathrm{mg} / \mathrm{kg}$ & i.v. & Post-anaesthesia & $\begin{array}{l}\text { Continues for } 140 \mathrm{~m} \\
\text { post-drug }\end{array}$ & - & $\begin{array}{l}\text { THC induced reduction in HR } \\
\text { through alteration of autonomic } \\
\text { innervation to myocardium. }\end{array}$ \\
\hline $\begin{array}{l}\text { Cavero } \\
1974[19]\end{array}$ & $\begin{array}{l}\text { Investigate the } \\
\text { effect of THC on } \\
\text { venous return }\end{array}$ & $\begin{array}{l}\text { Dogs (heart bypass) } \\
\text { Anaesthetised } \\
\text { (dibucaine, spinal) }\end{array}$ & 8 & $2.5 \mathrm{mg} / \mathrm{kg}$ & i.v. & Post-anaesthesia & $\begin{array}{l}\text { Pre-drug and continues } \\
\text { for } 30 \mathrm{~m} \text { post-drug }\end{array}$ & $\begin{array}{c}\text { C: HR:156, } \\
\text { BP:85.8; T: } \\
\text { HR:147, BP:85. }\end{array}$ & $\begin{array}{l}\text { THC caused reduction in HR } \\
\text { and BP, and reduced } \\
\text { venous return. }\end{array}$ \\
\hline $\begin{array}{l}\text { Daskalopoulos } \\
\quad 1975[28]\end{array}$ & $\begin{array}{c}\text { Investigate the } \\
\text { mechanism of THC } \\
\text { on CV system }\end{array}$ & $\begin{array}{l}\text { Cats Anaesthetised } \\
\text { (urethane, iv) }\end{array}$ & 40 & $30-300 \mu \mathrm{g} / \mathrm{kg}$ & i.v. & Post-anaesthesia & $20 \mathrm{~m}$ post-drug & - & $\begin{array}{c}\text { THC reduced HR and BP } \\
\text { mediated via central } \\
\text { nervous system. }\end{array}$ \\
\hline $\begin{array}{l}\text { Adams } \\
1976[29]\end{array}$ & $\begin{array}{l}\text { Examined the CV } \\
\text { effects of THC }\end{array}$ & $\begin{array}{l}\text { Rats Anaesthetised } \\
\text { (urethane, ip) }\end{array}$ & 72 & $0.1-3 \mathrm{mg} / \mathrm{kg}$ & i.v. & Post-anaesthesia & $\begin{array}{l}\text { Continues for } 30 \mathrm{~min} \\
\text { post-drug }\end{array}$ & $\begin{array}{l}\text { C: HR:316.2, } \\
\text { BP:76.2; T: } \\
\text { HR:314.8, } \\
\text { BP:73.5. }\end{array}$ & $\begin{array}{c}\text { THC caused reduction in HR } \\
\text { and biphasic BP response ( } \uparrow \text { BP } \\
\text { followed by } \downarrow \text { BP), suggesting } \\
\text { that THC depressed CV } \\
\text { reflex functions. }\end{array}$ \\
\hline $\begin{array}{l}\text { Jandhyala } \\
1976[30]\end{array}$ & $\begin{array}{l}\text { Evaluated possible } \\
\text { interaction with } \\
\text { THC on HR }\end{array}$ & $\begin{array}{l}\text { Dogs Anaesthetised } \\
\text { (pentobarbital) }\end{array}$ & 12 & $1 \mathrm{mg} / \mathrm{kg}$ & s.c. & $\begin{array}{l}\text { Twice/day for } \\
7 \text { days } \\
\text { Pre-anaesthesia }\end{array}$ & $\begin{array}{l}\text { On the } 7 \text { th day } \\
\text { post-anaesthesia }\end{array}$ & - & $\begin{array}{l}\text { Chronic THC antagonised the } \\
\text { elevation in HR induced by the } \\
\text { anaesthetic agent via } \\
\text { vagal stimulation. }\end{array}$ \\
\hline $\begin{array}{l}\text { Jandhyala } \\
1977 \text { [31] }\end{array}$ & $\begin{array}{l}\text { Determined chronic } \\
\text { administration of } \\
\text { THC on } \\
\text { CV function }\end{array}$ & $\begin{array}{l}\text { Dogs Anaesthetised } \\
\text { (pentobarbital) }\end{array}$ & 16 & $1 \mathrm{mg} / \mathrm{kg}$ & s.c. & $\begin{array}{l}\text { Twice/day for } \\
7 \text { days } \\
\text { Pre-anaesthesia }\end{array}$ & $\begin{array}{l}\text { On the 7th day } \\
\text { post-anaesthesia }\end{array}$ & - & $\begin{array}{l}\text { Chronic THC had no effect on } \\
\text { haemodynamics. }\end{array}$ \\
\hline $\begin{array}{l}\text { Jandhyala } \\
1978[32]\end{array}$ & $\begin{array}{l}\text { Investigated } \\
\text { prolonged THC } \\
\text { effects on } \\
\text { CV system }\end{array}$ & $\begin{array}{l}\text { Dogs Anaesthetised } \\
\text { (pentobarbital) }\end{array}$ & 16 & $2 \mathrm{mg} / \mathrm{kg}$ & s.c. & $\begin{array}{l}\text { Single dose per } \\
\text { day for } 35 \text { days }\end{array}$ & $\begin{array}{l}\text { On the 35th day } \\
\text { post-anaesthesia }\end{array}$ & - & $\begin{array}{l}\text { Chronic THC increased BF in } \\
\text { femoral and mesenteric arteries } \\
\text { with no effect on HR or BP. }\end{array}$ \\
\hline $\begin{array}{c}\text { McConnell } \\
1978 \text { [33] }\end{array}$ & $\begin{array}{l}\text { Examined the } \\
\text { effects of THC on } \\
\text { salivary flow }\end{array}$ & $\begin{array}{l}\text { Cats Anaesthetised } \\
\text { (urethane \& } \\
\text { pentobarbital, ip) }\end{array}$ & 20 & $0.1-2 \mathrm{mg} / \mathrm{kg}$ & i.v. & Post-anaesthesia & $\begin{array}{l}\text { Continues for } 1 \mathrm{~h} \\
\text { post-drug }\end{array}$ & - & $\begin{array}{l}\text { THC had no effect in stimulated } \\
\text { salivary flow of cats. THC } \\
\text { caused a reduction in HR and BP }\end{array}$ \\
\hline
\end{tabular}


Table 1. Cont.

\begin{tabular}{|c|c|c|c|c|c|c|c|c|c|}
\hline $\begin{array}{c}\text { Author \& } \\
\text { Year }\end{array}$ & Study Description & $\begin{array}{c}\text { Species, Model } \\
\text { (Anaesthetic \& Route) }\end{array}$ & Sample Size & THC Dose & THC Route & $\begin{array}{c}\text { Time of THC } \\
\text { Administration } \\
\end{array}$ & $\begin{array}{c}\text { Time of Haemodynamic } \\
\text { Measurements }\end{array}$ & $\begin{array}{c}\text { Basal } \\
\text { Parameters * }\end{array}$ & Outcomes and Comments \\
\hline \multicolumn{10}{|c|}{ Anaesthetised animals } \\
\hline $\begin{array}{l}\text { Siqueira } \\
1979[24]\end{array}$ & $\begin{array}{l}\text { Clarify the triple BP } \\
\text { response post-THC }\end{array}$ & $\begin{array}{l}\text { Rats Anaesthetised } \\
\text { (urethane, ip) }\end{array}$ & 50 & $1-10 \mathrm{mg} / \mathrm{kg}$ & i.v. & Post-anaesthesia & $\begin{array}{l}\text { Continues for } 70 \mathrm{~m} \\
\text { post-drug }\end{array}$ & - & $\begin{array}{l}\text { THC induced triphasic BP } \\
\text { response ( } \downarrow \text { BP via vagal } \\
\text { stimulation, then } \uparrow \text { BP not } \\
\text { dependent on sympathetic } \\
\text { activity followed by } \downarrow \text { BP due to } \\
\text { central decrease in } \\
\text { sympathetic tone). }\end{array}$ \\
\hline $\begin{array}{l}\text { Kawasaki } \\
1980[23]\end{array}$ & $\begin{array}{l}\text { Investigated the } \\
\text { effect of THC on the } \\
C V \text { system and } \\
\text { behavior changes }\end{array}$ & $\begin{array}{l}\text { Rats Anaesthetised } \\
\text { (urethane, ip) }\end{array}$ & 29 & $1-5 \mathrm{mg} / \mathrm{kg}$ & i.v. & Post-anaesthesia & $\begin{array}{l}\text { Continues for } 70 \mathrm{~m} \\
\text { post-drug }\end{array}$ & - & $\begin{array}{l}\text { THC induced CV effects ( } \downarrow \text { HR } \\
\text { and } \uparrow \text { BP) through vagal activity } \\
\text { and influence behavior changes } \\
\text { to brain stimulation. }\end{array}$ \\
\hline $\begin{array}{l}\text { Schmeling } \\
1981 \text { [34] }\end{array}$ & $\begin{array}{l}\text { Investigated the } \\
\text { effect of THC on } \\
\text { hypothalamus }\end{array}$ & $\begin{array}{l}\text { Cats Anaesthetised } \\
\text { (urethane, ip) }\end{array}$ & 12 & $2 \mathrm{mg} / \mathrm{kg}$ & i.v. & Post-anaesthesia & $\begin{array}{l}\text { Continues for } 30 \mathrm{~m} \\
\text { post-drug }\end{array}$ & - & $\begin{array}{l}\text { THC produced significant } \\
\text { reductions in HR and BP and } \\
\text { attenuated the pressor response } \\
\text { threshold suggesting that THC } \\
\text { reduces sympathetic activity. }\end{array}$ \\
\hline $\begin{array}{c}\text { Estrada } \\
1987[35]\end{array}$ & $\begin{array}{l}\text { Investigated the } \mathrm{CV} \\
\text { effects of THC }\end{array}$ & $\begin{array}{l}\text { Rats Anaesthetised } \\
\text { (pentobarbital, ip) }\end{array}$ & 28 & $0.078-5 \mathrm{mg} / \mathrm{kg}$ & i.v. & Post-anaesthesia & 3-12 min post-drug & - & $\begin{array}{c}\text { THC produced adverse effects } \\
\text { on the CV system ( } \downarrow \text { HR } \\
\text { and } \downarrow \text { BP) }\end{array}$ \\
\hline $\begin{array}{l}\text { Krowicki } \\
1999[36]\end{array}$ & $\begin{array}{c}\text { Investigated } \\
\text { whether } \mathrm{CB}_{1} \\
\text { activation by THC } \\
\text { inhibits gastric } \\
\text { motor function }\end{array}$ & $\begin{array}{l}\text { Rats Anaesthetised } \\
\text { (ketamine and } \\
\text { xylazine) }\end{array}$ & 36 & $0.02-2 \mathrm{mg} / \mathrm{kg}$ & i.v. & Post-anaesthesia & $\begin{array}{l}\text { Continues for } 10 \mathrm{~m} \\
\text { post-drug }\end{array}$ & - & $\begin{array}{c}\text { THC decreased gastric motor } \\
\text { function, } \mathrm{HR} \text {, and } \mathrm{BP} \text { via } \\
\text { autonomic effects mediated } \\
\text { by } \mathrm{CB}_{1} \text {. }\end{array}$ \\
\hline \multicolumn{10}{|c|}{ Conscious animals } \\
\hline $\begin{array}{l}\text { Kaymakcalan } \\
\quad 1974[37]\end{array}$ & $\begin{array}{c}\text { Investigated } \\
\text { chronic effects of } \\
\text { THC on HR }\end{array}$ & Rats Conscious & 20 & $10 \mathrm{mg} / \mathrm{kg}$ & s.c. & $\begin{array}{l}\text { Single dose per } \\
\text { day for } 16 \text { days }\end{array}$ & $\begin{array}{c}\text { Hourly interval to } 6 \mathrm{~h} \text { on } \\
\text { the } 1 \mathrm{st}, 4 \text { th, } 8 \text { th and } 16 \text { th } \\
\text { days }\end{array}$ & - & $\begin{array}{l}\text { THC produced marked } \\
\text { reduction in HR }\end{array}$ \\
\hline $\begin{array}{c}\text { Borgen } \\
1974[38]\end{array}$ & $\begin{array}{c}\text { Examined possible } \\
\text { interaction of CBD } \\
\text { on THC effects }\end{array}$ & Rabbits Conscious & 8 & $3 \mathrm{mg} / \mathrm{kg}$ & i.v. & Pre-test & $\begin{array}{l}\text { Pre-drug and hourly } \\
\text { interval to } 7 \mathrm{~h} \text { post-drug }\end{array}$ & $\begin{array}{l}\text { C: HR:264; T: } \\
\text { HR:276 }\end{array}$ & $\begin{array}{l}\text { CBD reduced the hypothermic } \\
\text { effect of THC and attenuated the } \\
\text { depressant effects of THC on } \\
\text { respiration, rectal temperature } \\
\text { and HR }\end{array}$ \\
\hline $\begin{array}{l}\text { Brown } \\
1974[20]\end{array}$ & $\begin{array}{l}\text { Investigated } \mathrm{CV} \\
\text { response to THC }\end{array}$ & Bats Conscious & 12 & 100 and $200 \mathrm{mg} / \mathrm{kg}$ & i.p. & Pre-test & $\begin{array}{l}\text { Pre-drug and continues } \\
\text { for } 145 \mathrm{~m} \text { post-drug }\end{array}$ & $\begin{array}{l}\text { C: HR:436, } \\
\text { BP:101; T: } \\
\text { HR:390, } \\
\text { BP:114 }\end{array}$ & $\begin{array}{l}\text { THC induced hypothermia and } \\
\text { reduction in HR and BP. }\end{array}$ \\
\hline
\end{tabular}


Table 1. Cont

\begin{tabular}{|c|c|c|c|c|c|c|c|c|c|}
\hline $\begin{array}{l}\text { Author \& } \\
\text { Year }\end{array}$ & Study Description & $\begin{array}{c}\text { Species, Model } \\
\text { (Anaesthetic \& Route) }\end{array}$ & Sample Size & THC Dose & THC Route & $\begin{array}{c}\text { Time of THC } \\
\text { Administration } \\
\end{array}$ & $\begin{array}{c}\text { Time of Haemodynamic } \\
\text { Measurements }\end{array}$ & $\begin{array}{c}\text { Basal } \\
\text { Parameters * }\end{array}$ & Outcomes and Comments \\
\hline \multicolumn{10}{|c|}{ Conscious animals } \\
\hline $\begin{array}{l}\text { Osgood } \\
1977[22]\end{array}$ & $\begin{array}{l}\text { Investigated THC } \\
\text { effects on } \mathrm{HR}\end{array}$ & Rats Conscious & 18 & $0.5 \mathrm{mg} / \mathrm{kg}$ & i.p. & Pre-test & $\begin{array}{l}\text { Continues for } 30 \mathrm{~m} \\
\text { post-drug }\end{array}$ & - & $\begin{array}{l}\text { THC had minimal effect on BP } \\
\text { and caused an increase in HR, } \\
\text { which may be related to central } \\
\text { mediation release of epinephrin } \\
\text { from adrenal gland. }\end{array}$ \\
\hline $\begin{array}{l}\text { Kawasaki } \\
1980[23]\end{array}$ & $\begin{array}{l}\text { Investigated the } \\
\text { effects of THC on } \\
\text { the CV system and } \\
\text { behavior changes }\end{array}$ & Rats Conscious & 21 & $4-8 \mathrm{mg} / \mathrm{kg}$ & i.p. & Pre-test & $\begin{array}{l}\text { Continues for } 2 \mathrm{~h} \\
\text { post-drug }\end{array}$ & - & $\begin{array}{l}\text { THC induced CV effects ( } \downarrow \text { HR } \\
\text { and } \uparrow \text { BP) through vagal activity y } \\
\text { and influenced behavior changes } \\
\text { to brain stimulation. }\end{array}$ \\
\hline $\begin{array}{l}\text { Matsuzaki } \\
1987 \text { [39] }\end{array}$ & $\begin{array}{l}\text { Examined the } \\
\text { effects of THC on } \\
\text { EEG, body } \\
\text { temperature, } \\
\text { and HR }\end{array}$ & Monkeys Conscious & 6 & $0.4-4 \mathrm{mg} / \mathrm{kg}$ & i.p. & Pre-test & $\begin{array}{l}\text { Continues for } 5 \mathrm{~h} \\
\text { post-drug }\end{array}$ & - & $\begin{array}{l}\text { THC induced reduction in HR } \\
\text { and hypothermia and induced } \\
\text { responses of EGG along with } \\
\text { behavioral depression } \\
\text { and alertness. }\end{array}$ \\
\hline $\begin{array}{l}\text { Hayakawa } \\
\text { 2007a }[40]\end{array}$ & $\begin{array}{l}\text { Investigated CBD } \\
\text { and THC effects on } \\
\text { ischemic brain } \\
\text { damage }\end{array}$ & Stroke Mice Conscious & 17 & $10 \mathrm{mg} / \mathrm{kg}$ & i.p. & $\begin{array}{l}\text { Pre-, } 3 \text { and } 4 \mathrm{~h} \\
\text { post-occlusion, } \\
\text { and } 1 \text { and } 2 \mathrm{~h} \\
\text { post-reperfusion }\end{array}$ & $\begin{array}{l}\text { BP and HR: } \\
\text { pre-reperfusion. CBF: } \\
\text { continued } 4 \mathrm{~h} \\
\text { post-occlusion and } 1 \\
\text { post-reperfusion }\end{array}$ & - & $\begin{array}{l}\text { Pre and post-ischemic treatment } \\
\text { with CBD induced } \\
\text { neuroprotection, whereas only } \\
\text { preischemic treatment with THC } \\
\text { induced neuroprotection. THC } \\
\text { increased CBF with no effects on } \\
\text { BP or HR }\end{array}$ \\
\hline $\begin{array}{l}\text { Hayakawa } \\
2007 b[41]\end{array}$ & $\begin{array}{l}\text { Explored the } \\
\text { development of } \\
\text { tolerance of THC } \\
\text { and CBD } \\
\text { neuroprotection }\end{array}$ & Stroke Mice Conscious & 7 & $10 \mathrm{mg} / \mathrm{kg}$ & i.p. & $\begin{array}{c}\text { Pre-occlusion and } \\
3 \text { h post-occlusion. } \\
\text { Single dose per } \\
\text { day for } 14 \text { days }\end{array}$ & $\begin{array}{l}\text { During } 4 \mathrm{~h} \text { and on day } 14 \\
\text { post-occlusion }\end{array}$ & - & $\begin{array}{l}\text { Repeated treatment with CBD, } \\
\text { but not THC, induced } \\
\text { neuroprotection with } \\
\text { development of tolerance. THC } \\
\text { increased CBF on day } 1 \text { only } \\
\text { with no effects on BP or HR. }\end{array}$ \\
\hline \multicolumn{10}{|c|}{ Stress and hypertensive animal models } \\
\hline $\begin{array}{l}\text { Williams } \\
1973[42] \\
\end{array}$ & $\begin{array}{l}\text { Studied the effects } \\
\text { of THC on BP }\end{array}$ & Rats Stress & 30 & $20 \mathrm{mg} / \mathrm{kg}$ & s.c. & $\begin{array}{l}\text { Single dose per } \\
\text { day for } 4 \text { days }\end{array}$ & $\begin{array}{l}\text { Pre-drug, } 4 \mathrm{~h}, 48 \text { and } 96 \mathrm{~h} \\
\text { post-drug }\end{array}$ & $\begin{array}{l}\text { C: BP:128; T: } \\
\text { BP:129 }\end{array}$ & THC reduced BP \\
\hline $\begin{array}{c}\text { Birmingham } \\
1973 \text { [43] }\end{array}$ & $\begin{array}{l}\text { Studies the effects } \\
\text { of THC on BP }\end{array}$ & Rats Hypertensive & 10 & $3 \mathrm{mg} / \mathrm{kg}$ & i.p. & $\begin{array}{c}\text { Single dose per } \\
\text { day for } 7 \text { days }\end{array}$ & Hourly to $5 \mathrm{~h}$ for 7 days & - & THC reduced $\mathrm{BP}$ \\
\hline $\begin{array}{l}\text { Kosersky } \\
1978[44]\end{array}$ & $\begin{array}{l}\text { Examined the } \\
\text { antihypertensive } \\
\text { effects of THC }\end{array}$ & Rats Hypertensive & 12 & $25 \mathrm{mg} / \mathrm{kg}$ & Oral & $\begin{array}{l}\text { Single dose per } \\
\text { day for } 10 \text { days }\end{array}$ & $\begin{array}{l}4 \mathrm{~h} \text { and every day for } 14 \\
\text { days post-drug }\end{array}$ & - & $\begin{array}{l}\text { THC effectively reduced BP to } \\
\text { the same degree over the } \\
\text { treatment period. }\end{array}$ \\
\hline
\end{tabular}


Table 1. Cont.

\begin{tabular}{|c|c|c|c|c|c|c|c|c|c|}
\hline $\begin{array}{l}\text { Author \& } \\
\text { Year }\end{array}$ & Study Description & $\begin{array}{c}\text { Species, Model } \\
\text { (Anaesthetic \& Route) }\end{array}$ & Sample Size & THC Dose & THC Route & $\begin{array}{c}\text { Time of THC } \\
\text { Administration }\end{array}$ & $\begin{array}{c}\text { Time of Haemodynamic } \\
\text { Measurements }\end{array}$ & $\begin{array}{c}\text { Basal } \\
\text { Parameters * }\end{array}$ & Outcomes and Comments \\
\hline \multicolumn{10}{|c|}{ Humans } \\
\hline $\begin{array}{c}\text { Karniol } \\
1973[45]\end{array}$ & $\begin{array}{l}\text { Compared the } \\
\text { effects of } 8 \text {-THC } \\
\text { and } 9 \text {-THC }\end{array}$ & Human Healthy & 21 & 5-20 mg & Inhale & Pre-test & Avrg. of $20 \mathrm{~m}$ post-drug & $\begin{array}{l}\text { C: HR: } 82 ; \text { T: } \\
\text { HR: } 85\end{array}$ & $\begin{array}{l}\text { 9-THC was twice as active as } \\
\text { 8-THC in increasing HR and } \\
\text { caused more } \\
\text { subjective symptoms. }\end{array}$ \\
\hline $\begin{array}{c}\text { Karniol } \\
1975[46]\end{array}$ & $\begin{array}{l}\text { Examined the } \\
\text { interaction between } \\
\text { THC and CBN }\end{array}$ & Human Healthy & $5(\mathrm{M})$ & $25 \mathrm{mg}$ & Oral & Pre-test & $\begin{array}{l}50,70 \text { and } 160 \mathrm{~m} \\
\text { post-drug }\end{array}$ & - & $\begin{array}{l}\text { THC induced increase in HR and } \\
\text { psychological effects. No change } \\
\text { on THC effects when combined } \\
\text { with CBN }\end{array}$ \\
\hline $\begin{array}{l}\text { Zimmer } \\
1976[47]\end{array}$ & $\begin{array}{l}\text { Examined changes } \\
\text { of somatic } \\
\text { parameters } \\
\text { post-THC }\end{array}$ & Human Healthy & 36 & $250 \mu \mathrm{g} / \mathrm{kg}$ & Oral & Pre-test & $\begin{array}{l}\text { Pre-drug and } 4 \mathrm{~h} \\
\text { post-drug }\end{array}$ & $\begin{array}{l}\text { C: HR:87.9, } \\
\text { BP:127.5; ;: } \\
\text { HR: } 89, \text { BP: } 123\end{array}$ & $\begin{array}{l}\text { THC raised HR with no changes } \\
\text { on other parameters } \\
\text { including BP }\end{array}$ \\
\hline $\begin{array}{c}\text { Haney } \\
2007[48]\end{array}$ & $\begin{array}{l}\text { Determined the } \\
\text { effects of naltrexone } \\
\text { in combination } \\
\text { with THC }\end{array}$ & Human Healthy & 21 (11 M \& $10 \mathrm{~F})$ & $2.5-10 \mathrm{mg}$ & Oral & Pre-test & $\begin{array}{l}\text { Continues for } 6 \mathrm{~h} \\
\text { post-drug }\end{array}$ & - & $\begin{array}{c}\text { Naltrexone enhanced } \\
\text { intoxication effects of THC; THC } \\
\text { increased HR }\end{array}$ \\
\hline $\begin{array}{l}\text { Beaumont } \\
2009 \text { [21] }\end{array}$ & $\begin{array}{l}\text { Evaluated whether } \\
\text { THC has inhibitory } \\
\text { effect on transient } \\
\text { esophageal sphincter }\end{array}$ & Human Healthy & 18 (M) & 10 and $20 \mathrm{mg}$ & Oral & Pre-test & $\begin{array}{l}\text { Continues for } 4 \mathrm{~h} \\
\text { post-drug }\end{array}$ & $\begin{array}{l}\text { C: HR:59; T: } \\
\text { HR:59 }\end{array}$ & $\begin{array}{l}\text { THC inhibited the increased } \\
\text { induced meal transient } \\
\text { esophageal sphincter relaxation. } \\
\text { THC increased HR and } \\
\text { decreased BP }\end{array}$ \\
\hline $\begin{array}{c}\text { Klooker } \\
2011[49]\end{array}$ & $\begin{array}{l}\text { Assessed the effect } \\
\text { of THC on rectal } \\
\text { sensation }\end{array}$ & $\begin{array}{l}\text { Human Healthy } \\
\text { and IBD }\end{array}$ & 10 and 12 & 5 and $10 \mathrm{mg}$ & Oral & Pre-test & $\begin{array}{l}\text { Continues for } 105 \mathrm{~m} \\
\text { post-drug }\end{array}$ & - & $\begin{array}{l}\text { THC had no effect on rectal } \\
\text { perception to distension. THC } \\
\text { increased HR with no effect } \\
\text { on BP }\end{array}$ \\
\hline
\end{tabular}




\subsection{Effect of THC Treatment on Haemodynamics}

\subsubsection{Anaesthetised Animals}

Fifteen publications [19,23-36] assessed the effect of THC administration in three anaesthetised species (rats, dogs, and cats, $n=664)$. THC significantly reduced BP and HR after acute dosing (BP, MD - 19.7 mmHg, 95\%CI - 26.16, - 13.25, $p<0.00001$; HR, MD - 53.49 bpm, 95\%CI - 65.9, - 41.07, $p<0.00001$, Figure 2A,B). A cross-species analysis revealed that THC responses in the three species were significantly different in both BP $(p<0.00001)$ and HR $(p=0.01)$ (Figure 2A,B), and acute THC significantly reduced BP in rats and cats, but not in anesthetised dogs $(p=0.18$, Figure $2 \mathrm{~A})$.

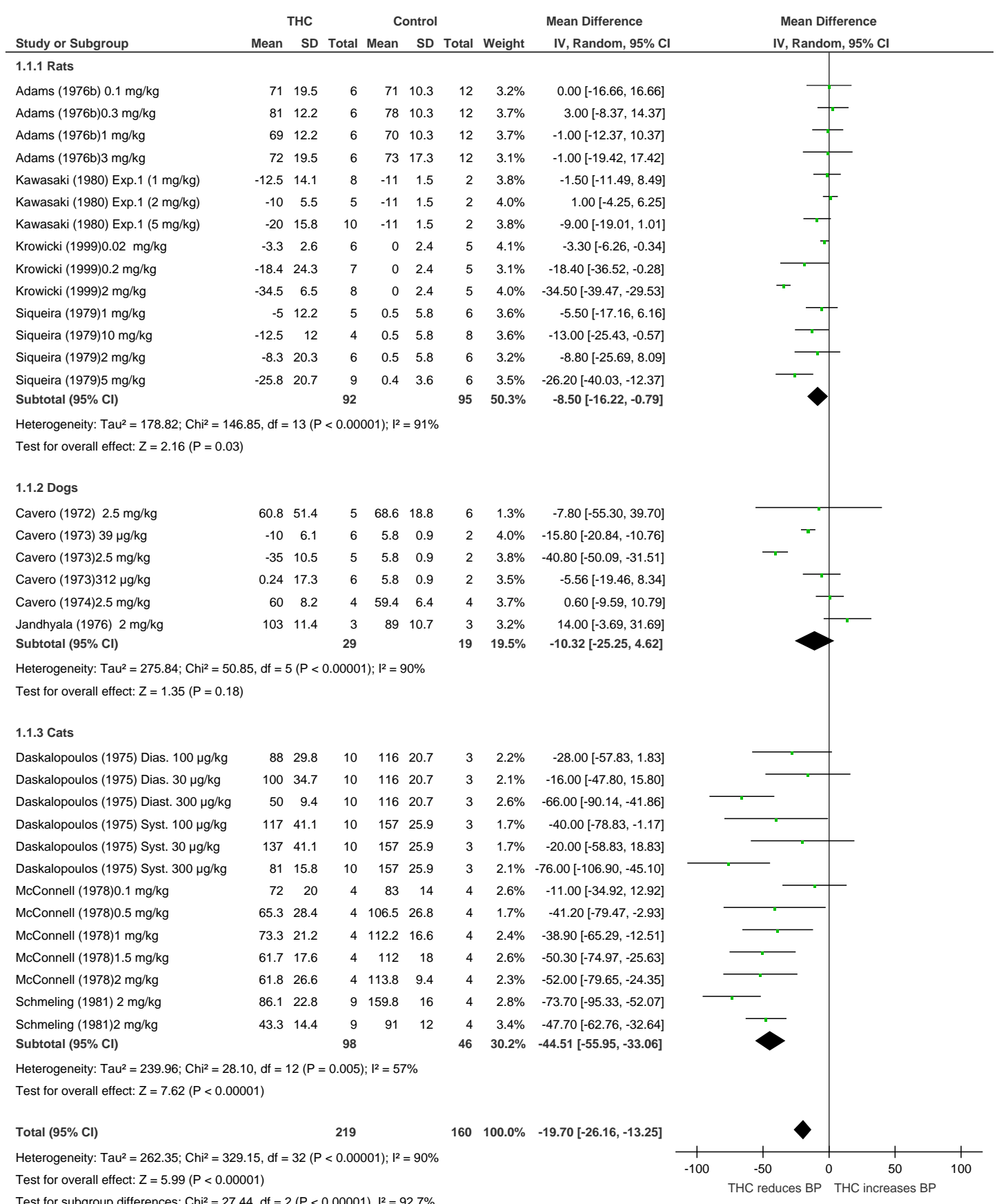

Figure 2. Cont. 


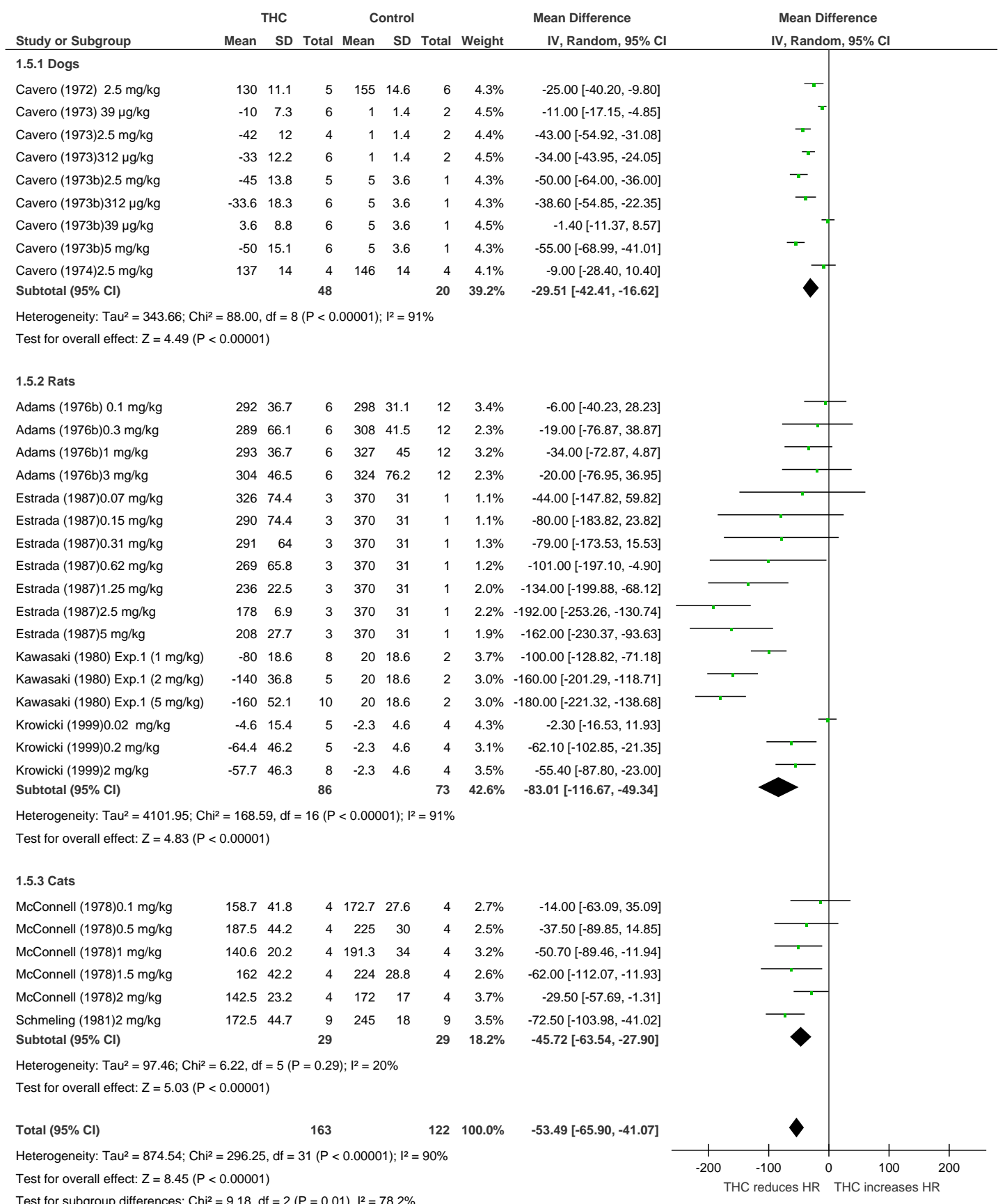

Figure 2. Changes in (A) BP and (B) HR induced by acute THC dosing in anaesthetised animals.

Chronic THC administration (7-35 days) tended to increase mesenteric, femoral, and renal BF $(p=0.05$, Figure $3 \mathrm{C}$ ) with no significant effect on HR or BP. Heterogeneity was statistically significant for BP and HR measurements after acute THC dosing $\left(p<0.00001 ; \mathrm{I}^{2}=90 \%\right)$ and for BP after chronic THC dosing (BP, $p=0.03, \mathrm{I}^{2}=72 \%$ ). 


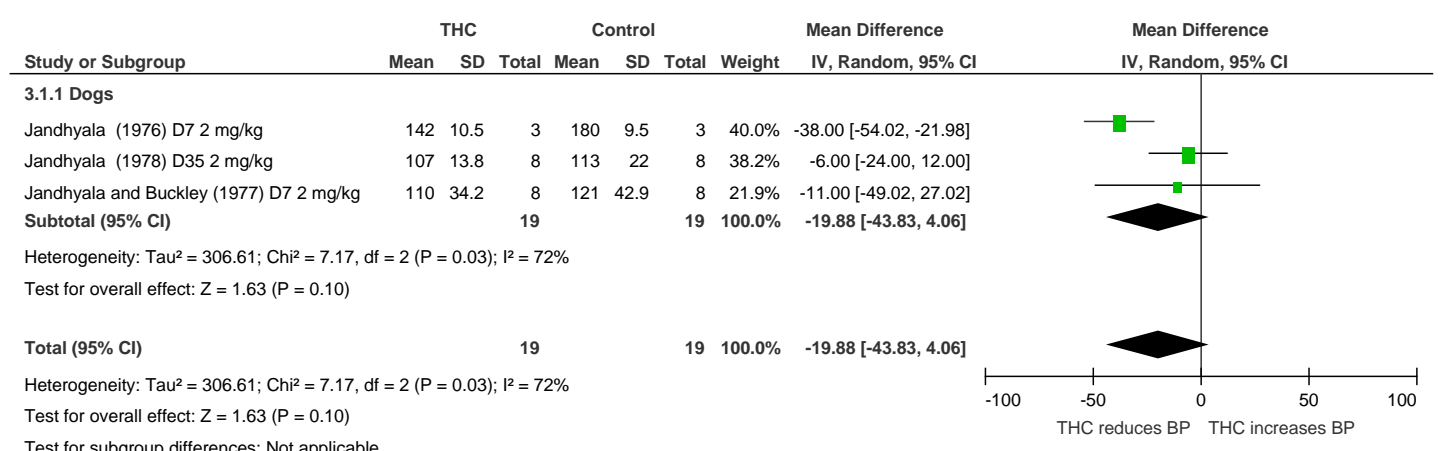

(A)

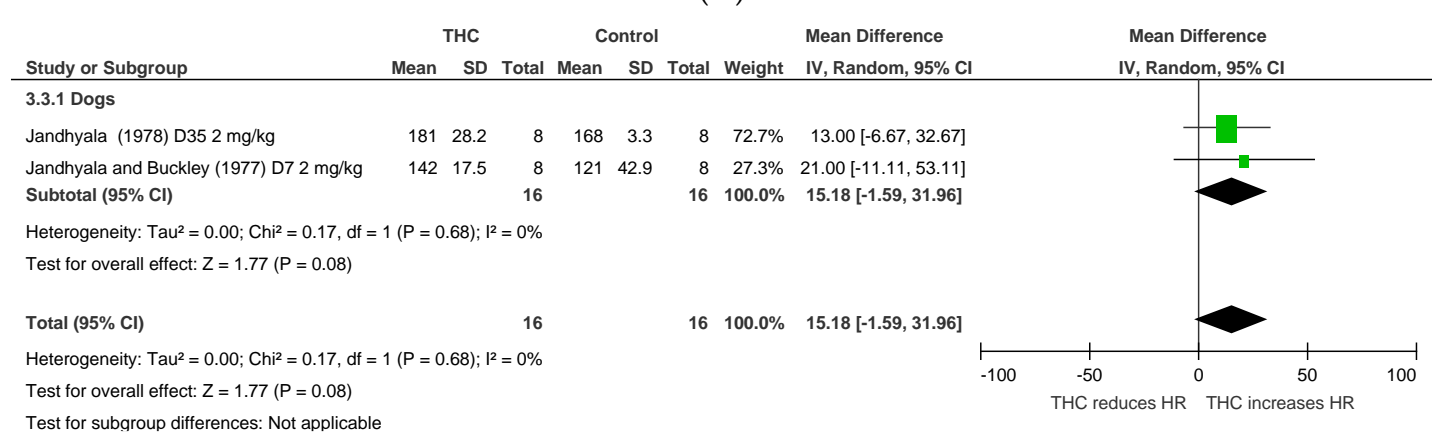

(B)

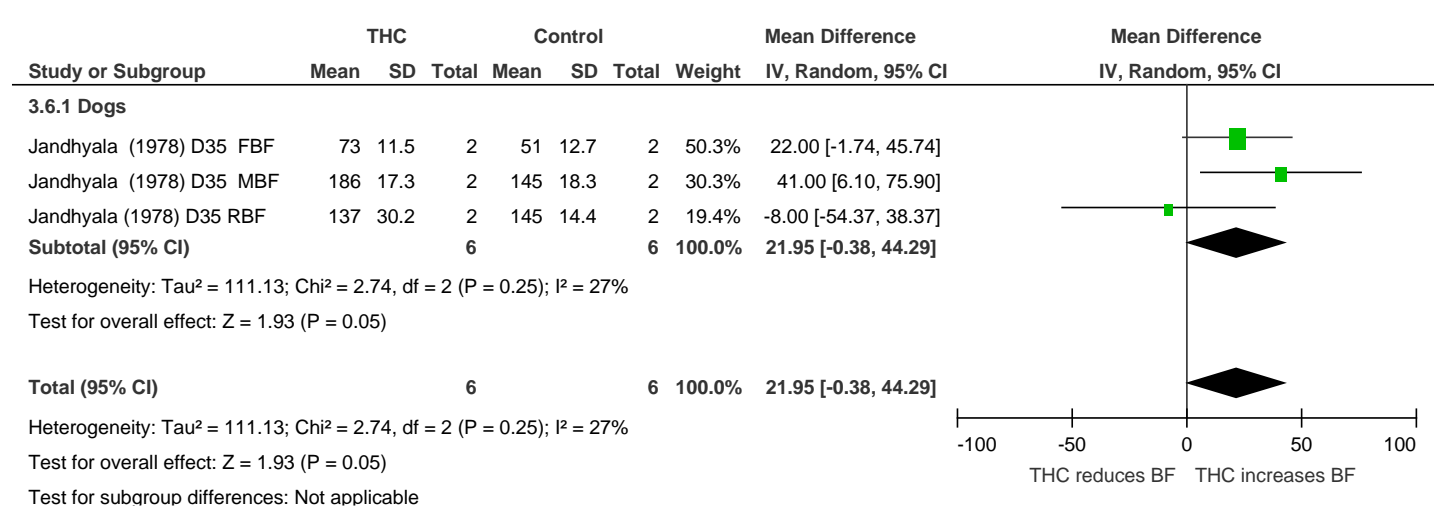

(C)

Figure 3. Changes in (A) blood pressure, (B) heart rate, and (C) blood flow (BF) induced by chronic THC dosing in anaesthetised animals.

\subsubsection{Conscious Animals}

Eight publications $[20,22,23,37-41]$ assessed the effect of THC administration in five conscious species, including rats, bats, mice, rabbits, and monkeys $(n=170)$. THC significantly reduced BP and HR after acute dosing (BP, MD $-12.3 \mathrm{mmHg}, 95 \% \mathrm{CI}-19.42,-5.18, p=0.0007$; HR, MD $-30.05 \mathrm{bpm}$, $95 \% \mathrm{CI}-38.47,-21.64, p<0.00001$, Figure $4 \mathrm{~A}, \mathrm{~B})$, and significantly increased CBF in murine models of stroke (BF, MD 32.35\%, 95\%CI 23.81, 40.88, $p<0.00001$, Figure 4C). A cross-species analysis revealed that acute THC did not affect BP in bats $(p=0.36)$ and rats $(p=0.11)$ (Figure $4 \mathrm{~B})$. Heterogeneity was statistically significant for BP and HR measurements after acute THC dosing (BP, $p<0.00001, \mathrm{I}^{2}=83 \%$; $\left.\mathrm{HR}, p<0.00001, \mathrm{I}^{2}=87 \%\right)$, but not in $\mathrm{BF}\left(p=0.5, \mathrm{I}^{2}=0 \%\right)$.

\subsubsection{Conscious Animal Models of Stress or Hypertension}

Two publications $[43,44]$ assessed the effect of THC administration on BP in hypertensive rats $(n=22)$, and one [42] in a rat model of stress $(n=30)$. Acute and chronic $(4-10$ days $)$ THC dosing 
significantly reduced BP (acute THC, $\mathrm{MD}-61.37 \mathrm{mmHg}, 95 \% \mathrm{CI}-117.56,-5.17, p=0.03$, Figure 5A; chronic THC, MD - 22.09 mmHg, 95\% CI -30.61, -13.58, $p<0.00001$, Figure 5B). Heterogeneity was statistically significant after acute dosing $\left(p<0.00001, \mathrm{I}^{2}=99 \%\right)$, but not after chronic dosing $(p=0.69$, $\left.\mathrm{I}^{2}=0 \%\right)$.

\subsubsection{Human Studies}

Six publications [21,45-49] assessed the acute effect of THC administration on HR in humans $(n=150)$, no studies examined BP or BF. THC significantly increased HR after acute dosing (HR, MD 8.16 bpm, 95\% CI 4.99, 11.33, $p<0.00001$, Figure 6). Heterogeneity was statistically significant $\left(p<0.00001 ; \mathrm{I}^{2}=76 \%\right)$.

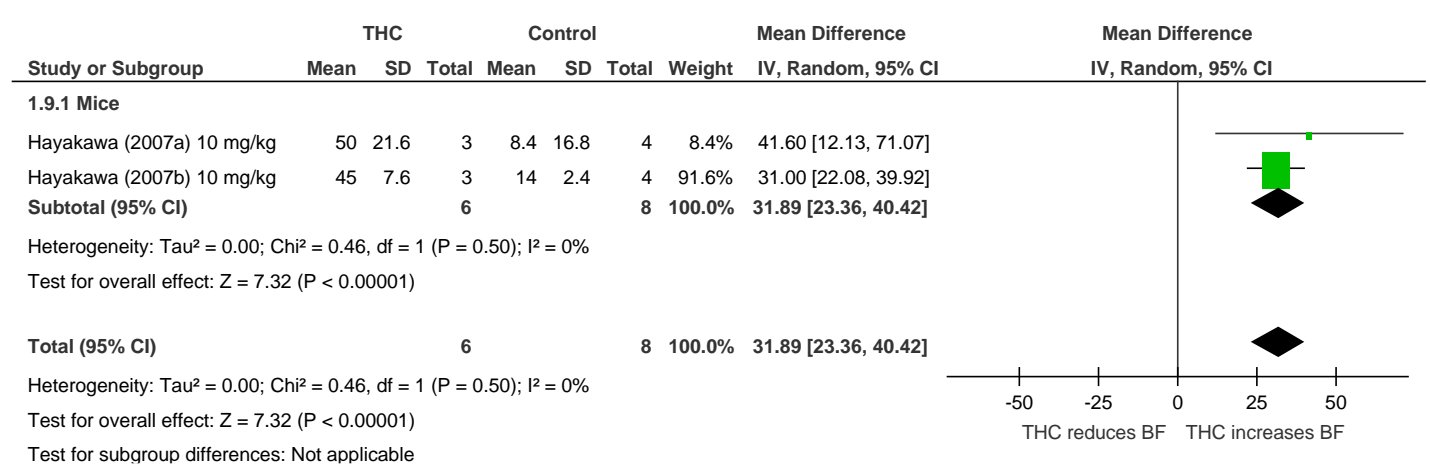

(A)

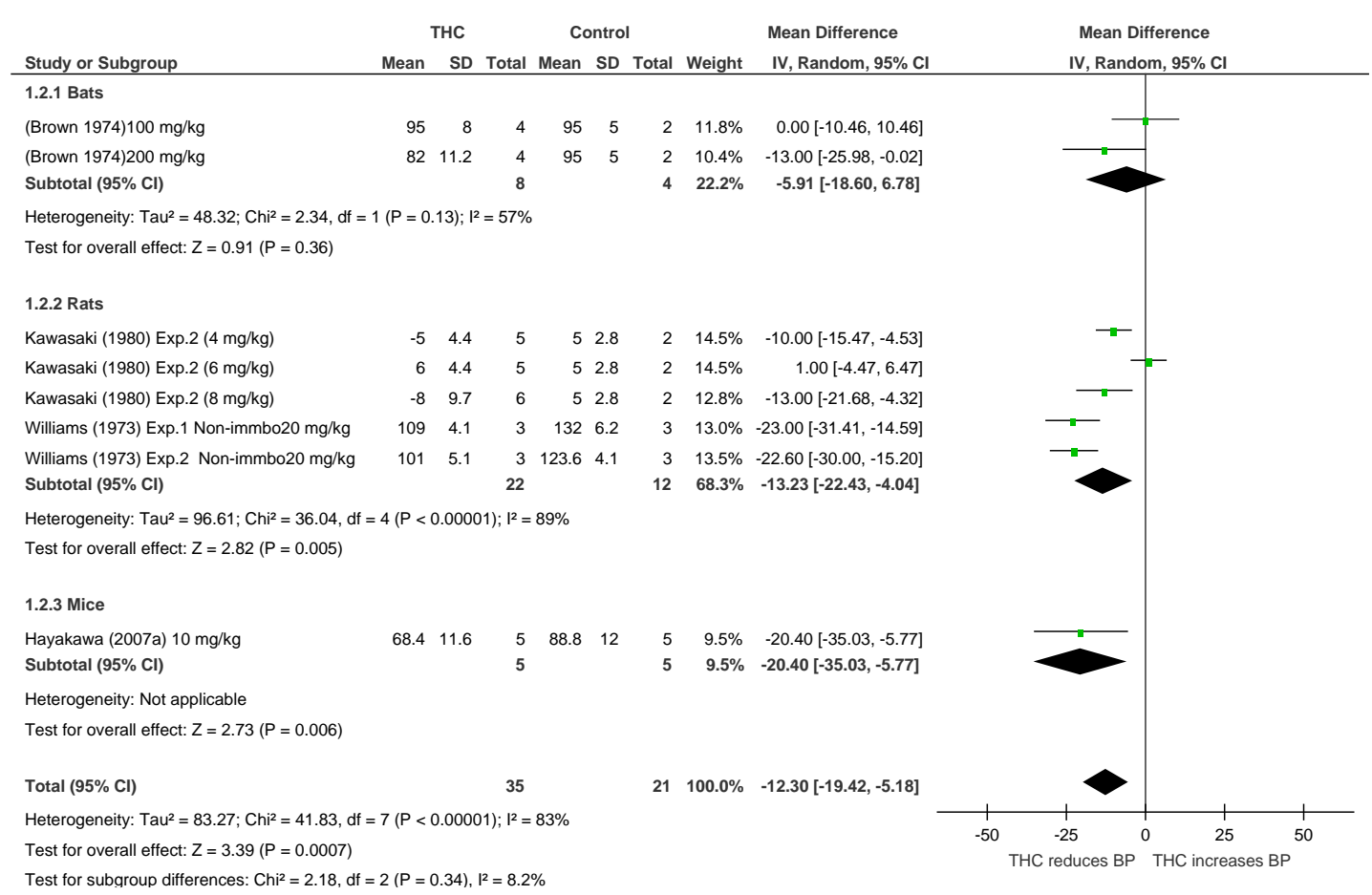

(B)

Figure 4. Cont. 


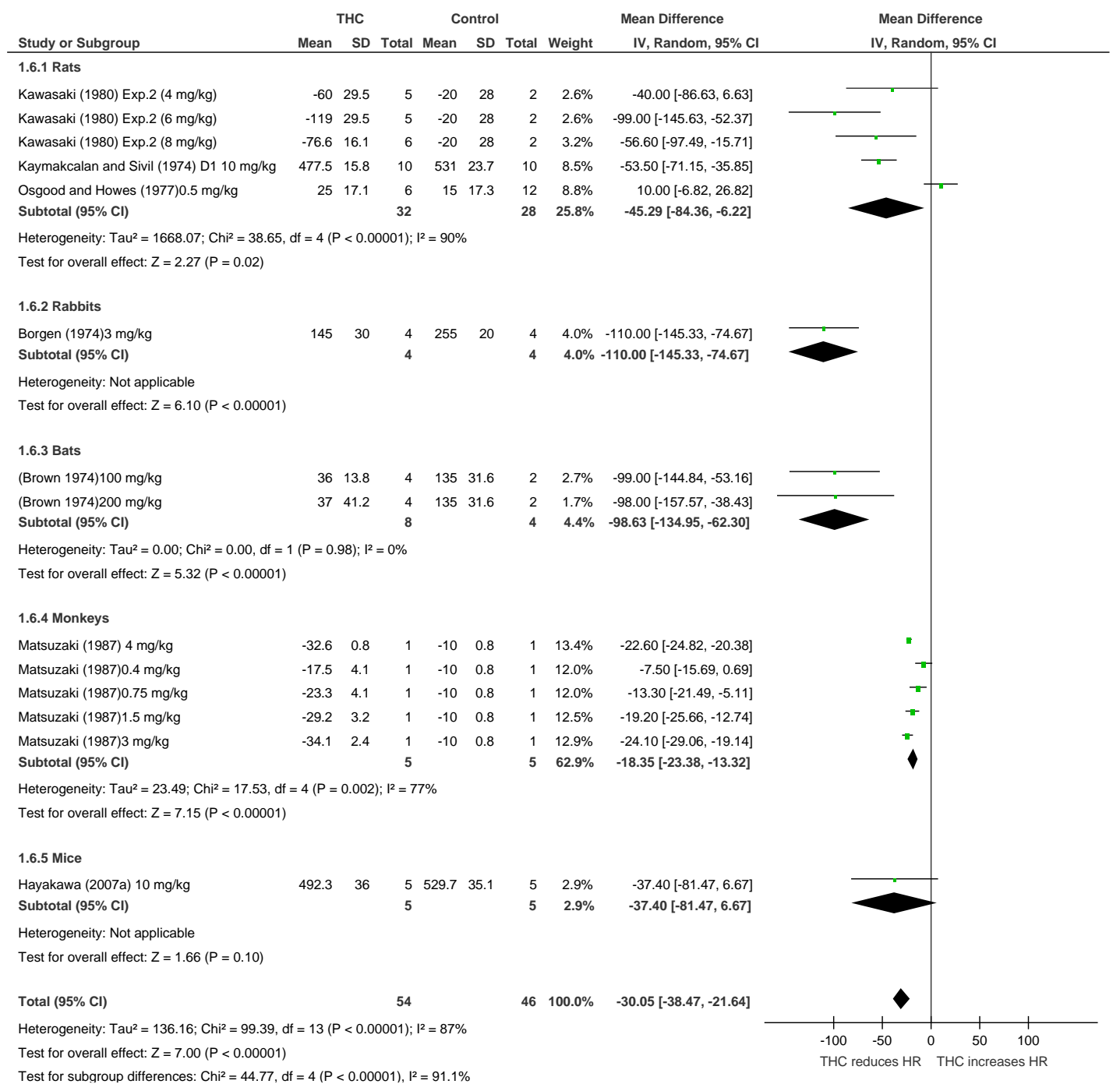

(C)

Figure 4. Changes in (A) BP, (B) HR, and (C) blood flow induced by acute THC dosing in conscious animals.

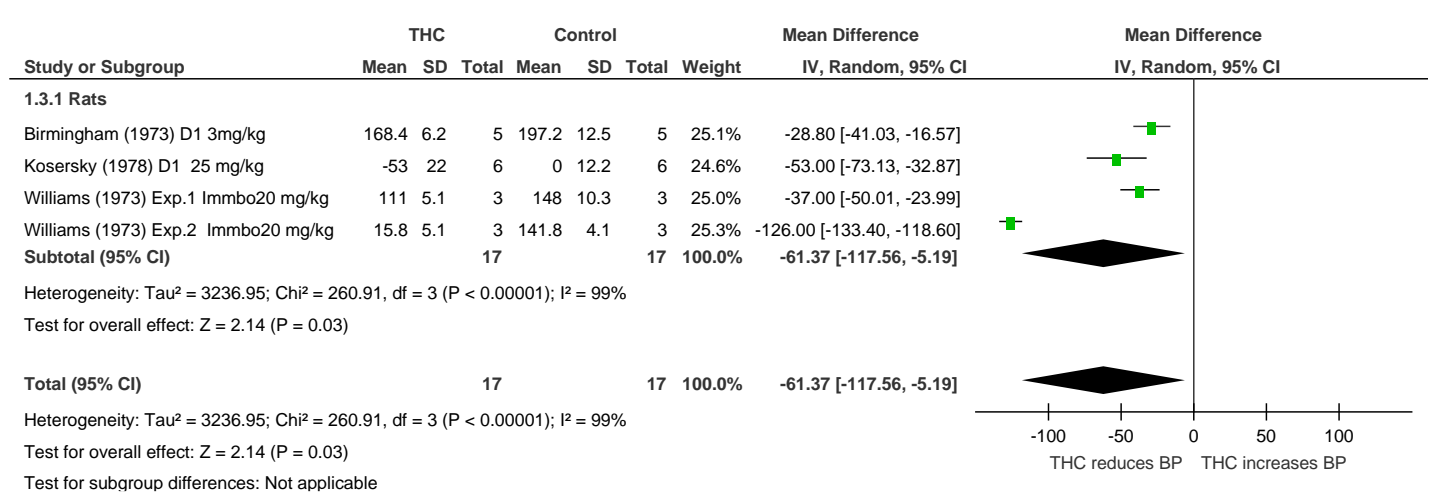

(A)

Figure 5. Cont. 


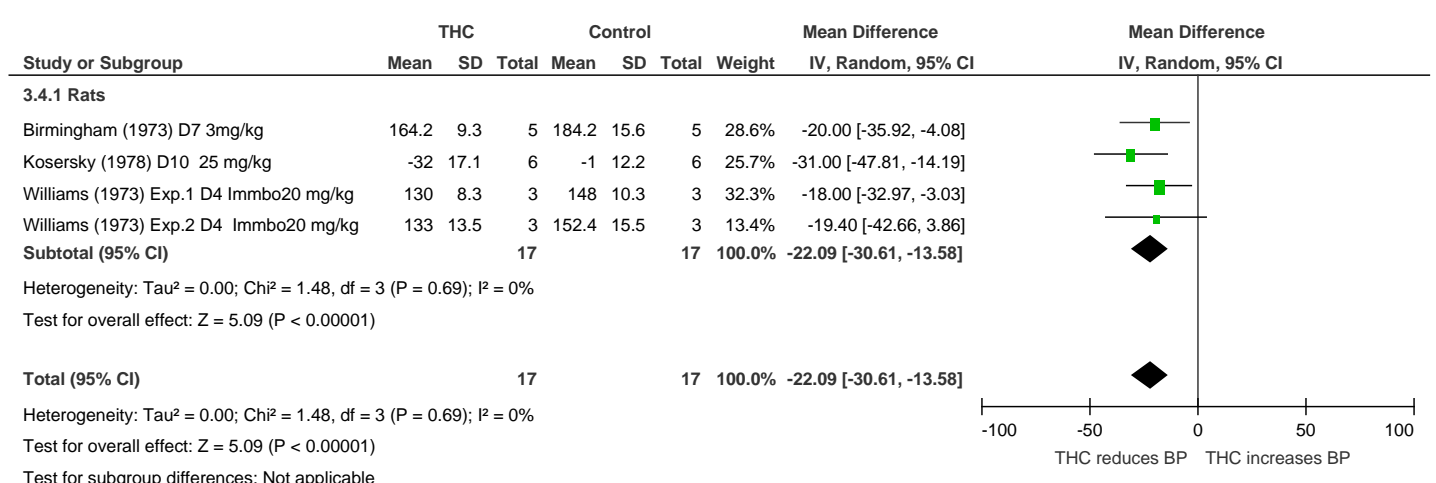

(B)

Figure 5. Changes in BP induced by (A) acute and (B) chronic THC dosing in animal models of stress or hypertension.

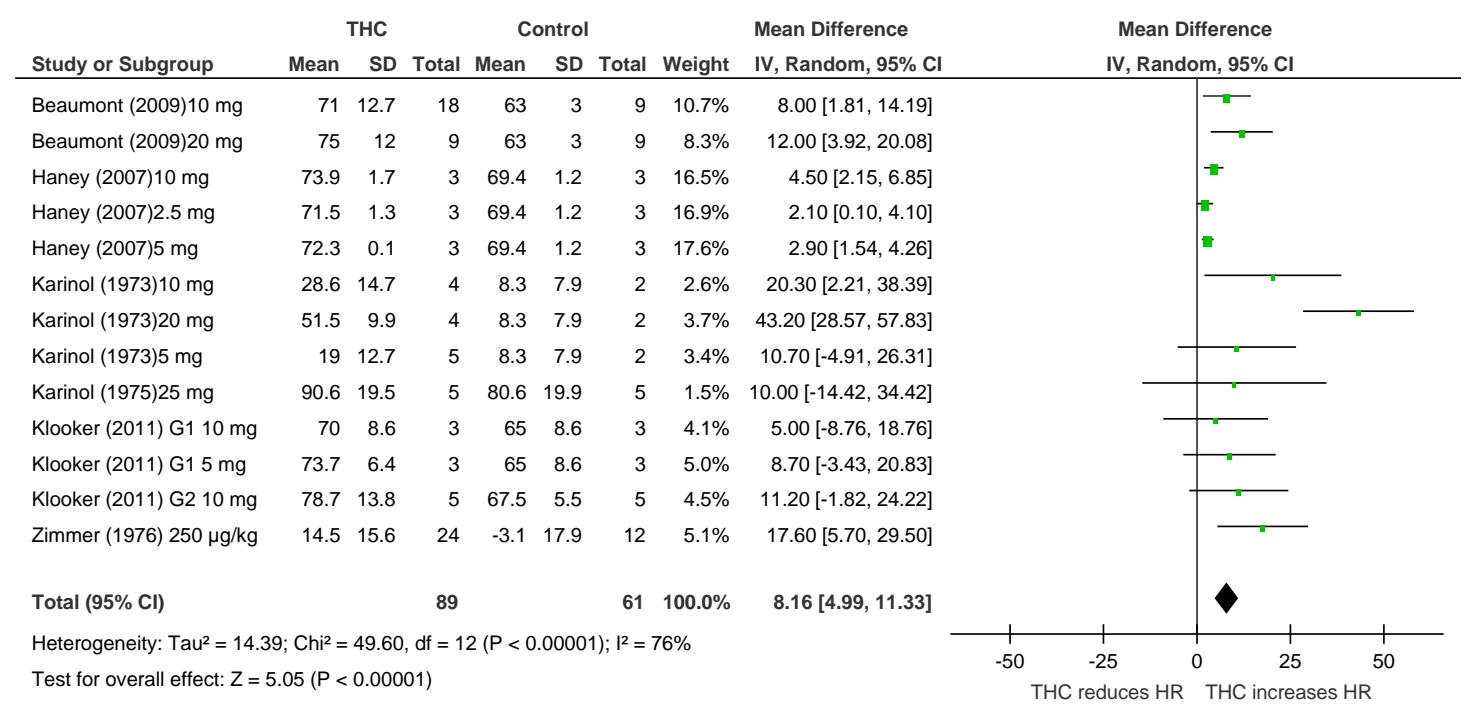

Figure 6. Changes in HR induced by acute THC dosing in humans.

\subsection{Dose-Response to THC}

Doses ranging from 0.0003 to $770 \mathrm{mg}$ were used in different species. The animal analyses showed a trend in the reduction of BP with higher THC doses $(p=0.07)$, with no change in HR. In humans, THC caused dose-dependent tachycardia $(p=0.01)$ (Figure 7).

A

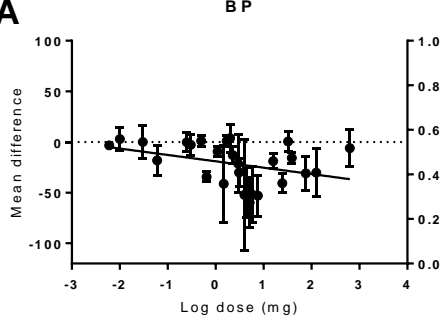

B

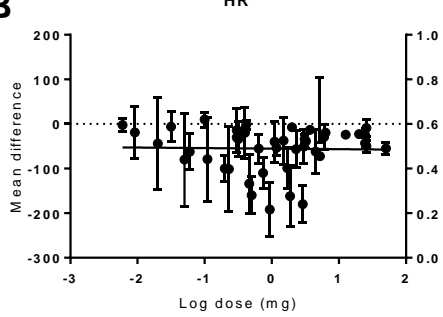

C

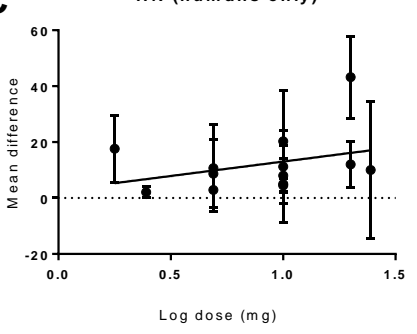

Figure 7. The effect of different THC doses on haemodynamic responses in vivo. The mean difference (MD) in animals' blood pressure (BP, (A)), animals' heart rate $(\mathrm{HR},(\mathbf{B}))$, or heart rate (in humans only) $(p=0.01)(\mathrm{HR},(\mathbf{C}))$ is plotted against the log dose $(\mathrm{mg})$ for each study. Error bars represent $95 \%$ confidence intervals (CI). Near-significant and significant dose-dependent effects on the blood pressure in animals $(p=0.07)$ and on the HR in humans $(p=0.01)$. 


\subsection{Quality}

Among the 31 included publications, 6 publications used randomisation in their design and reported blinding assessment of outcome and measurements. Twenty publications assessed more than one outcome, 19 conducted dose-response relationships, 26 assessed a time window for intervention, 11 measured outcomes $>24 \mathrm{~h}$ post-drug, and no publications provided incomplete data. There was no significant relationship between the quality score and any outcome (Spearman's rho coefficient of BP $0.22, p=0.09$; HR $0.27, p=0.07$ and BF $0.58, p=0.3$ ).

\subsection{Publication Bias}

Egger's test showed that bias was present in all studies except in studies in anaesthetised animals, conscious animals $(p=0.001)$, animal models of stress or hypertension (C) $(p=0.001)$, and humans (D) $(p<0.0001)$ (Appendix A, Figure A1).

\section{Discussion}

The aim of this study was to determine the effect of THC on haemodynamics in vivo in animals and cannabis-naïve humans. Our analysis has shown that an acute dosing of THC reduced BP and $\mathrm{HR}$, and increased BF in animals of different models. Chronic dosing of THC tended to increase BF in anaesthetised animals and reduced BP in animal models of stress or hypertension. The data concerning the effects of THC in humans was limited to HR only, revealing a dose-dependent increase, suggesting further work is required to determine the full haemodynamic effects of acute and chronic THC administration in humans, especially given the different effects of THC on HR observed across species.

Our meta-analysis showed that acute THC dosing in anaesthetised animals reduced BP and HR, while a subgroup analysis revealed that there was no effect on BP or HR of anaesthetised dogs. However, Cavero et al. $(1972,1973,1974)$ reported that intravenous administration of THC induced hypotension and bradycardia in dogs anaesthetised with pentobarbital caused by a reduction in the cardiac output and venous return mediated by the autonomic system [19,25-27]. Similarly, Schmeling reported that the reduction in sympathetic activity induced by THC in cats may cause hypotension and bradycardia [34]. It is suggested that the vagus nerve and the sympathetic outflow play a role in these effects induced by THC [36] and can be inhibited by the administration of a $\mathrm{CB}_{1}$ antagonist [50]. The administration of THC for seven days subcutaneously reduced the increase in HR induced by pentobarbital anaesthetic agent in dogs, suggesting that THC antagonises the pentobarbital effect on the parasympathetic system (inhibiting the vagal tone) [30]. In rats anesthetised with pentobarbital, hypotension was reported after the administration of THC [35]; on the contrary, hypertension was reported in rats anesthetised with urethane post-THC [36], suggesting that THC may act differently with different anaesthetic agents. These studies suggest that the effects of THC in anaesthetised animals (hypotension and bradycardia) are induced through a central mechanism via the activation of $\mathrm{CB}_{1}$ receptors.

In conscious animals under normal conditions, THC caused a variety of effects: hypotension was observed in bats, an effect which may be related to a change in venous activity [20], whereas another study in rats reported that THC induced tachycardia and hypertension, which are centrally mediated by increasing the level of adrenaline in the circulation [22]. However, studies in rat models of stress and hypertension, showed that THC lowered BP effectively [42-44]. The mechanism of the antihypertensive effect of THC in these models still needs to be studied.

Our meta-analysis in cannabis-naïve humans highlighted the limited number of studies investigating the effect of THC in humans ( 6 publications, $n=123$ participants) with insufficient data to meta-analyse BP or regional BF. Studies in cannabis-naïve volunteers showed that the administration of THC orally or by inhalation caused tachycardia [46-49,51]. Tachycardia is also reported in humans after smoking cannabis [52-54] which may indicate that tachycardia induced post-cannabis smoking is caused by THC. The increase in HR caused by THC can be inhibited by $\mathrm{CB}_{1}$ antagonism [55], suggesting 
that $\mathrm{CB}_{1}$ activation may play a role in the haemodynamic effect of THC in humans. A greater number of studies investigating the haemodynamic effect of THC and its mechanisms under normal and pathological conditions in humans are required.

Several studies have reported that phytocannabinoids such as cannabidiol (CBD) may alter the effect of THC. For example, Borgen and Davis suggested that CBD may act as a potential antagonist of the THC effect on HR in rabbits and rats [38] and protects against some of the negative effects of THC in humans with potentially opposite effects on regional brain functions [56,57]. The combination of CBD and THC such as in Sative ${ }^{\circledR}$, a licenced agent for the symptomatic treatment of spasticity in multiple sclerosis, has shown that CBD inhibits the tachycardia effect induced by THC in humans [58].

Dose-response analyses showed a relationship between THC dose and effect size on BP, but not HR, in different animal models, and on human HR. Dose-dependent effects on BP were also observed post-THC in anaesthetized rats [24,36], cats [28], and dogs [26]. A dose of 100 and $200 \mathrm{mg}$ caused a dose-dependent reduction on the BP of conscious bats, but not on HR [20]. HR dose-dependent reduction was reported in anaesthetized dogs [26,27] and conscious monkeys [39]. In human studies, doses between 2.5 and $25 \mathrm{mg}$ were used. A dose-dependent increase in HR was observed in humans after oral THC administration of 5, 10, and $20 \mathrm{mg}[21,49]$. Over-intoxication has been reported after $20 \mathrm{mg}$ of oral administration of THC in 5 of 21 healthy volunteers [48].

There are a number of limitations to consider in this analysis. First, the principal intention of 10 of the included studies was not to assess the cardiovascular effects of THC administration; therefore, the data extracted through secondary haemodynamic outcomes in this meta-analysis is for hypothesis-generating purposes. Second, the results should be interpreted with caution because of the heterogeneity between studies in terms of THC dose, time, and route of administration; the responses to THC will clearly be dependent upon peak plasma concentration, which are not easily comparable across studies. Indeed, a significant statistical heterogeneity was observed in the majority of the meta-analyses. Third, only 6 out of 31 articles used randomisation and described a masked assessment of outcomes, factors that can influence the reported outcomes. However, we found no significant correlation between study quality and effect size in this review.

In conclusion, this study has summarised the in vivo cardiovascular effects of THC administration. Our analysis demonstrates that THC acts differently according to species, causing tachycardia in humans, and bradycardia, hypotension, and an increase in regional BF in animals under different conditions. THC may be a potential future treatment for cardiovascular disorders, though its use as a single agent will be limited by $\mathrm{CB}_{1}$ mediated psychogenic side effects, events that could be counterbalanced with other agents such as CBD. Data from human studies using THC alone is limited to heart rate only, thereby further good quality, randomised, blinded studies investigating the haemodynamic effects of THC in humans should be considered.

\section{Materials and Methods}

\subsection{Search Strategy}

All studies investigating the haemodynamic effects of THC (including BP, HR, and BF) were searched for (until April 2017) in Medline, EMBASE, and PubMed. Search keywords included: $\Delta^{9}$-Tetrahydrocannabinol, Tetrahydrocannabinol, THC, Dronabinol, Marinol, Nabilone, Namisol, cardiovascular, blood pressure, systolic, diastolic, hypertension, hypotension, heart rate, tachycardia, bradycardia, blood flow, haemodynamic, vasodilation, vasorelaxation, and vasoconstriction. References from the included studies were also hand-searched.

Prespecified inclusion and exclusion criteria were used to prevent bias; the studies had to be in vivo, assess haemodynamics (BP, HR or BF), be original articles, be controlled studies, and use cannabis-naïve participants. Therefore, the exclusion criteria were: in vitro studies, mixtures of $\Delta^{9}$-THC with other cannabis extracts, studies investigating the interaction of THC with other drugs or 
cannabinoids, studies not assessing haemodynamics (BP, HR, or BF), review articles, editorials, and uncontrolled studies.

\subsection{Data Acquisition}

Data on BP (mmHg), HR (beats per minute, bpm), and BF (\% change from baseline or $\mathrm{mL} / \mathrm{min}$ ) were extracted from the included papers, and the changes in haemodynamics $2 \mathrm{~h}$ post-drug after acute THC dosing were used for the analyses. This time point was selected as the peak plasma time is between $30 \mathrm{~min}$ and $4 \mathrm{~h}$ after oral administration and it was the most common time point when haemodynamics were measured throughout the articles. If there were no measurements taken at this time point ( $2 \mathrm{~h}$ post-drug), the closest time point to $2 \mathrm{~h}$ was used for the analyses. In chronic studies, the measurements taken at the end of the studies were used for the analyses. If the exact number of animals used in each drug group was not available, the lowest number of animals within the range given was used for the experimental group (THC), and the highest number was used for the control group. If a crossover design was used in a study, the total number of humans was distributed equally to the two groups. Articles were excluded if data were not available. Grab application (version 1.5) was used to extract values from the figures given in published articles if no values were stated within the text. If the published articles used multiple groups (e.g., to assess dose-dependent effects) with one control group, then the number of humans or animals per control group was divided into the number of comparison groups. For the dose-response analysis, the total dose of the drug administrated up to the time when the haemodynamics was measured was used.

\subsection{Quality}

Eight-point criteria derived from Stroke Therapy Academic Industry Recommendations (STAIR) [59-61] and the Cochrane collaborations tool [62] were used to identify the risk of bias. Each of the following criteria was equal to 1 point: randomisation, blinding of outcome assessment, blinding of personnel and participant, assessment of more than one outcome, dose-response relationship, therapeutic time window, assessment of outcome $>24 \mathrm{~h}$, and incomplete outcome data.

\subsection{Data Analysis}

The studies were divided into acute and chronic groups. The data from human and animal studies were analysed separately. The animals were divided into two groups, anaesthetised and conscious, as the autonomic nervous system may respond differently in the two conditions [63], then grouped before the analysis in normal and abnormal (i.e., models of stress or hypertension) models and then subgrouped by species (mice, rats, dogs, etc.). For the THC dose-response analysis, the data were grouped according to the endpoint (BP, HR, or BF), and then subgrouped according to the dose. The data from each group were analysed as forest plots using the Cochrane Review Manager software (Version 5.3. Copenhagen: The Nordic Cochrane Centre, The Cochrane Collaboration, 2014), and as funnel plots using Stata (StataCorp. 2009. Stata Statistical Software: Release 11. College Station, TX, USA). Funnel plot asymmetry (publication bias) was assessed by Egger's test [64]. Stata was also used for meta-regression that described the relationship between THC dose and effect size. PRISM 7 (GraphPad, Software, La Jolla, CA, USA) was used to produce the figures of dose-response. Since heterogeneity was expected between the study protocols (different species, models, dose, and time) random-effect models were used. The results of continuous data are expressed as mean difference (MD) with $95 \%$ confidence intervals (CIs). The studies were weighted by sample size, and statistical significance was set at $p<0.05$.

Author Contributions: T.J.E. and S.E.O. conceived and designed the experiments; S.R.S. and S.A.M. collected and analyzed the data; all authors wrote and revised the manuscript.

Conflicts of Interest: The authors declare no conflict of interest. 


\section{Appendix A}

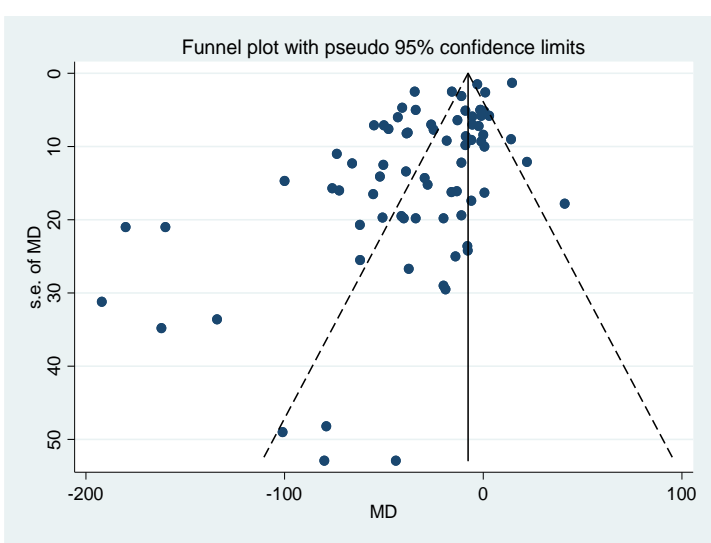

(A) Anaesthetised animals

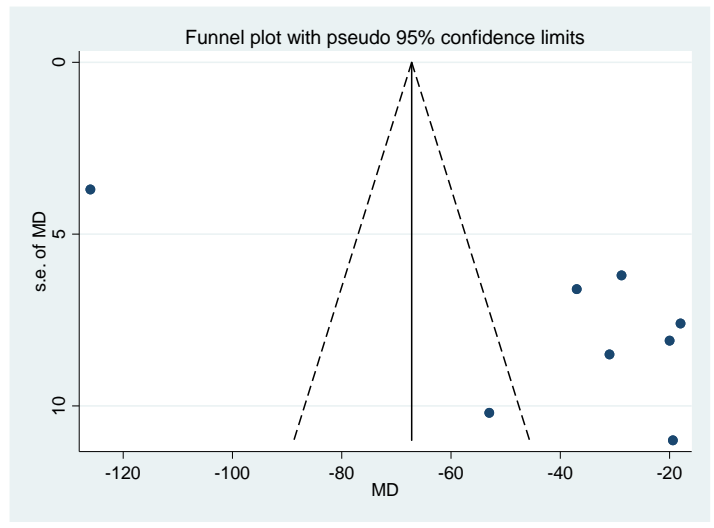

(C) Animal models of stress or hypertension

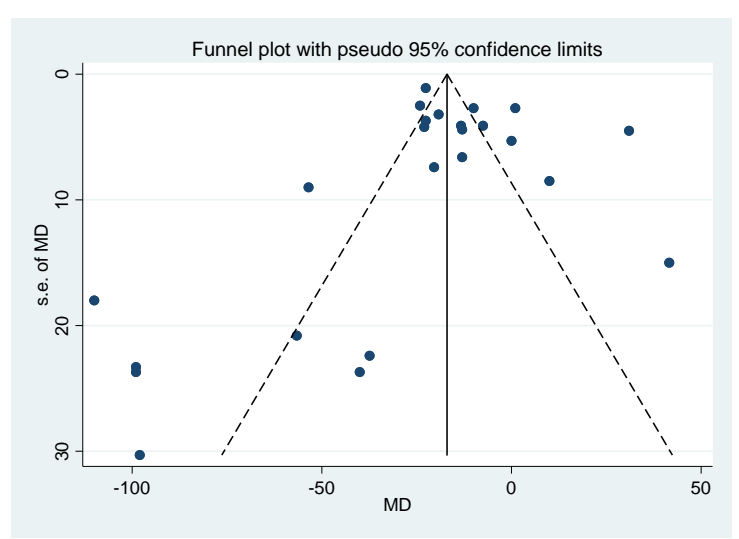

(B) Conscious animals

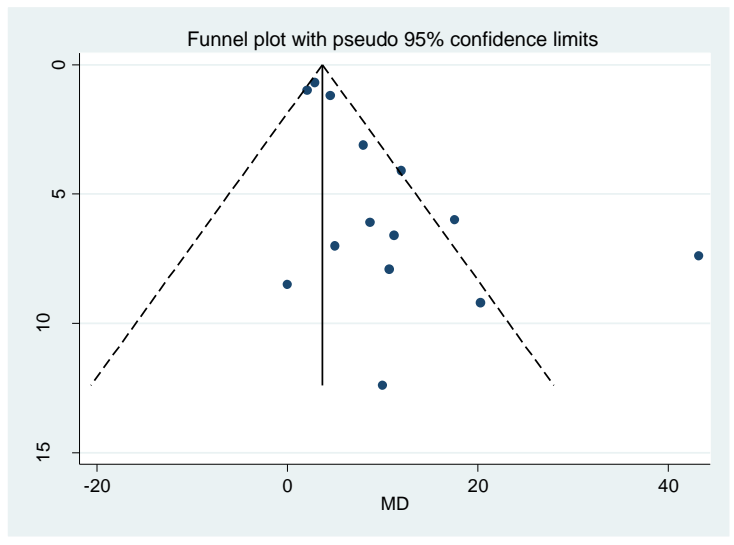

(D) Humans

Figure A1. Funnel plots for each outcome evaluating the publication bias. The standard error (SE) of the mean difference (MD) in haemodynamics (MD, $y$ axis) for each study is plotted against its effect size (horizontal axis). There was significant bias in conscious animals $(\mathbf{B})(p=0.001)$, animal models of stress or hypertension $(\mathbf{C})(p=0.001)$, and humans $(\mathbf{D})(p<0.0001)$. No significant bias in anaesthetised animals (A).

\section{References}

1. Gaoni, Y.; Mechoulam, R. Isolation, Structure, and Partial Synthesis of an Active Constituent of Hashish. J. Am. Chem. Soc. 1964, 86, 1646-1647. [CrossRef]

2. Pertwee, R.G. Pharmacological actions of cannabinoids. Handb. Exp. Pharmacol. 2005, 20, 1-51.

3. Ryberg, E.; Larsson, N.; Sjögren, S.; Hjorth, S.; Hermansson, N.O.; Leonova, J.; Elebring, T.; Nilsson, K.; Drmota, T.; Greasley, P.J. The orphan receptor GPR55 is a novel cannabinoid receptor. Br. J. Pharmacol. 2007, 152, 1092-1101. [CrossRef] [PubMed]

4. McHugh, D.; Page, J.; Dunn, E.; Bradshaw, H.B. Delta(9) -Tetrahydrocannabinol and N-arachidonyl glycine are full agonists at GPR18 receptors and induce migration in human endometrial HEC-1B cells. Br. J. Pharmacol. 2012, 165, 2414-2424. [CrossRef] [PubMed]

5. Ben Amar, M. Cannabinoids in medicine: A review of their therapeutic potential. J. Ethnopharmacol. 2006, 105, 1-25. [CrossRef] [PubMed]

6. Lastres-Becker, I.; Molina-Holgado, F.; Ramos, J.A.; Mechoulam, R.; Fernandez-Ruiz, J. Cannabinoids provide neuroprotection against 6-hydroxydopamine toxicity in vivo and in vitro: Relevance to Parkinson's disease. Neurobiol. Dis. 2005, 19, 96-107. [CrossRef] [PubMed] 
7. Buccellato, E.; Carretta, D.; Utan, A.; Cavina, C.; Speroni, E.; Grassi, G.; Candeletti, S.; Romualdi, P. Acute and chronic cannabinoid extracts administration affects motor function in a CREAE model of multiple sclerosis. J Ethnopharmacol. 2011, 133, 1033-1038. [CrossRef] [PubMed]

8. Whiting, P.F.; Wolff, R.F.; Deshpande, S.; Di Nisio, M.; Duffy, S.; Hernandez, A.V.; Keurentjes, J.C.; Lang, S.; Misso, K.; Ryder, S.; et al. Cannabinoids for Medical Use: A Systematic Review and Meta-analysis. JAMA 2015, 313, 2456-2473. [CrossRef] [PubMed]

9. Todaro, B. Cannabinoids in the treatment of chemotherapy-induced nausea and vomiting. J. Natl. Compr. Cancer Netw. 2012, 10, 487-492. [CrossRef]

10. Abrams, D.I.; Guzman, M. Cannabis in cancer care. Clin. Pharmacol. Ther. 2015, 97, 575-586. [CrossRef] [PubMed]

11. Fleming, I.; Schermer, B.; Popp, R.; Busse, R. Inhibition of the production of endothelium-derived hyperpolarizing factor by cannabinoid receptor agonists. Br. J. Pharmacol. 1999, 126, 949-960. [CrossRef] [PubMed]

12. Zygmunt, P.M.; Andersson, D.A.; Högestätt, E.D. $\Delta^{9}$ Tetrahydrocannabinol and Cannabinol Activate Capsaicin-Sensitive Sensory Nerves via a CB1 and CB2 Cannabinoid Receptor-Independent Mechanism. J. Neurosci. 2002, 22, 4720-4727. [PubMed]

13. O'Sullivan, S.E.; Kendall, D.A.; Randall, M.D. The effects of $\Delta(9)$-tetrahydrocannabinol in rat mesenteric vasculature, and its interactions with the endocannabinoid anandamide. Br. J. Pharmacol. 2005, 145, 514-526. [CrossRef] [PubMed]

14. O'Sullivan, S.E.; Kendall, D.A.; Randall, M.D. Vascular effects of delta 9-tetrahydrocannabinol (THC), anandamide and $\mathrm{N}$-arachidonoyldopamine (NADA) in the rat isolated aorta. Eur. J. Pharmacol 2005, 507, 211-221. [CrossRef] [PubMed]

15. O'Sullivan, S.E.; Tarling, E.J.; Bennett, A.J.; Kendall, D.A.; Randall, M.D. Novel time-dependent vascular actions of Delta9-tetrahydrocannabinol mediated by peroxisome proliferator-activated receptor gamma. Biochem. Biophys. Res. Commun. 2005, 337, 824-831. [CrossRef] [PubMed]

16. Kaymakcalan, S.; Turker, R.K. The evidence of the release of prostaglandin-like material from rabbit kidney and guinea-pig lung by (minus)-trans-delta9-tetrahydrocannabinol. J. Pharm. Pharmacol. 1975, 27, 564-568. [CrossRef] [PubMed]

17. Duncan, M.; Kendall, D.A.; Ralevic, V. Characterization of cannabinoid modulation of sensory neurotransmission in the rat isolated mesenteric arterial bed. J. Pharmacol. Exp. Ther. 2004, 311, 411-419. [CrossRef] [PubMed]

18. Barbosa, P.P.; Lapa, A.J.; Lima-Landman, M.T.; Valle, J.R. Vasoconstriction induced by delta 9-tetrahydrocannabinol on the perfused rabbit ear artery. Arch. Int. Pharmacodyn. Ther. 1981, 252, $253-261$. [PubMed]

19. Cavero, I.; Lokhandwala, M.F.; Buckley, J.P.; Jandhyala, B.S. The effect of (-)- $\Delta^{9}$-trans-tetrahydrocannabinol on myocardial contractility and venous return in anesthetized dogs. Eur. J. Pharmacol. 1974, 29, 74-82. [CrossRef]

20. Brown, D.J.; Miller, F.N.; Longnecker, D.E.; Greenwald, E.K.; Harris, P.D.; Forney, R.B. The influence of delta 9-tetrahydrocannabinol on cardiovascular and subcutaneous microcirculatory systems in the bat. J. Pharmacol. Exp. Ther. 1974, 188, 624-629. [PubMed]

21. Beaumont, H.; Jensen, J.; Carlsson, A.; Ruth, M.; Lehmann, A.; Boeckxstaens, G. Effect of delta9tetrahydrocannabinol, a cannabinoid receptor agonist, on the triggering of transient lower oesophageal sphincter relaxations in dogs and humans. Br. J. Pharmacol. 2009, 156, 153-162. [CrossRef] [PubMed]

22. Osgood, P.F.; Howes, J.F. $\Delta^{9}$-tetrahydrocannabinol and dimethylheptylpyran induced tachycardia in the conscious rat. Life Sci. 1977, 21, 1329-1335. [CrossRef]

23. Kawasaki, H.; Watanabe, S.; Oishi, R.; Ueki, S. Effects of delta-9-tetrahydrocannabinol on the cardiovascular system, and pressor and behavioral responses to brain stimulation in rats. Jpn. J. Pharmacol. 1980, 30, 493-502. [CrossRef] [PubMed]

24. Siqueira, S.W.; Lapa, A.J.; Ribeiro do Valle, J. The triple effect induced by delta 9-tetrahydrocannabinol on the rat blood pressure. Eur. J. Pharmacol. 1979, 58, 351-357. [CrossRef]

25. Cavero, I.; Ertel, R.; Buckley, J.P.; Jandhyala, B.S. Effects of (-)- $\Delta^{9}$-trans-tetrahydrocannabinol on regional blood flow in anesthetized dogs. Eur. J. Pharmacol. 1972, 20, 373-376. [CrossRef] 
26. Cavero, I.; Buckley, J.P.; Jandhyala, B.S. Hemodynamic and myocardial effects of (-)- $\Delta 9$-transtetrahydrocannabinol in anesthetized dogs. Eur. J. Pharmacol. 1973, 24, 243-251. [CrossRef]

27. Cavero, I.; Solomon, T.; Buckley, J.P.; Jandhyala, B.S. Studies on the bradycardia induced by (-)-delta9trans-tetrahydrocannabinol in anesthetized dogs. Eur. J. Pharmacol. 1973, 22, 263-269. [CrossRef]

28. Daskalopoulos, N.; Schmitt, H.; Laubie, M. Action of delta 9 tetrahydrocannabinol on the central cardiovascular regulation: Mechanism and localization. Lencephale 1975, 1, 121-132.

29. Adams, M.D.; Earnhardt, J.T.; Dewey, W.L.; Harris, L.S. Vasoconstrictor actions of delta8- and delta9-tetrahydrocannabinol in the rat. J. Pharmacol. Exp. Ther. 1976, 196, 649-656. [PubMed]

30. Jandhyala, B.S.; Malloy, K.P.; Buckley, J.P. Effects of chronic administration of delta9-tetrahydrocannabinol on the heart rate of mongrel dogs. Res. Commun. Chem. Pathol. Pharmacol. 1976, 14, 201-204. [PubMed]

31. Jandhyala, B.S.; Buckley, J.P. Autonomic and cardiovascular effects of chronic delta9-tetrahydrocannabinol administration in mongrel dogs. Res. Commun. Chem. Pathol. Pharmacol. 1977, 16, 593-607. [PubMed]

32. Jandhyala, B.S. Effects of prolonged administration of delta 9-tetrahydrocannabinol on the autonomic and cardiovascular function and regional hemodynamics in mongrel dogs. Res. Commun. Chem. Pathol. Pharmacol. 1978, 20, 489-508. [PubMed]

33. McConnell, W.R.; Dewey, W.L.; Harris, L.S.; Borzelleca, J.F. A study of the effect of delta 9-tetrahydrocannabinol (delta 9-THC) on mammalian salivary flow. J. Pharmacol. Exp. Ther. 1978, 206, 567-573. [PubMed]

34. Schmeling, W.T.; Hosko, M.J.; Hardman, H.F. Potentials evoked in the intermediolateral column by hypothalamic stimulation-Suppression by $\Delta$ 9-tetrahydrocannabinol. Life Sci. 1981, 29, 673-680. [CrossRef]

35. Estrada, U.; Brase, D.A.; Martin, B.R.; Dewey, W.L. Cardiovascular effects of delta 9- and delta 9(11)-tetrahydrocannabinol and their interaction with epinephrine. Life Sci. 1987, 41, 79-87. [CrossRef]

36. Krowicki, Z.K.; Moerschbaecher, J.M.; Winsauer, P.J.; Digavalli, S.V.; Hornby, P.J. Delta9-tetrahydrocannabinol inhibits gastric motility in the rat through cannabinoid CB1 receptors. Eur. J. Pharmacol. 1999, 371, 187-196. [CrossRef]

37. Kaymakcalan, S.; Sivil, S. Lack of tolerance to the bradycardic effect of delta 9-trans-tetrahydrocannabinol in rats. Pharmacology 1974, 12, 290-295. [PubMed]

38. Borgen, L.A.; Davis, W.M. Cannabidiol interaction with delta9-tetrahydrocannabinol. Res. Commun. Chem. Pathol. Pharmacol. 1974, 7, 663-670. [PubMed]

39. Matsuzaki, M.; Casella, G.A.; Ratner, M. delta 9-Tetrahydrocannabinol: EEG changes, bradycardia and hypothermia in the rhesus monkey. Brain Res. Bull. 1987, 19, 223-229. [CrossRef]

40. Hayakawa, K.; Mishima, K.; Nozako, M.; Hazekawa, M.; Irie, K.; Fujioka, M.; Orito, K.; Abe, K.; Hasebe, N.; Egashira, N.; et al. Delayed treatment with cannabidiol has a cerebroprotective action via a cannabinoid receptor-independent myeloperoxidase-inhibiting mechanism. J. Neurochem. 2007, 102, 1488-1496. [CrossRef] [PubMed]

41. Hayakawa, K.; Mishima, K.; Nozako, M.; Ogata, A.; Hazekawa, M.; Liu, A.X.; Fujioka, M.; Abe, K.; Hasebe, N.; Egashira, N.; et al. Repeated treatment with cannabidiol but not Delta9-tetrahydrocannabinol has a neuroprotective effect without the development of tolerance. Neuropharmacology 2007, 52, 1079-1087. [CrossRef] [PubMed]

42. Williams, R.B.; Ng, L.K.Y.; Lamprecht, F.; Roth, K.; Kopin, I.J. $\Delta$ 9-Tetrahydrocannabinol: A hypotensive effect in rats. Psychopharmacologia 1973, 28, 269-274. [CrossRef] [PubMed]

43. Birmingham, M.K. Reduction by 9-tetrahydrocannabinol in the blood pressure of hypertensive rats bearing regenerated adrenal glands. Br. J. Pharmacol. 1973, 48, 169-171. [CrossRef] [PubMed]

44. Kosersky, D.S. Antihypertensive effects of delta9-tetrahydrocannabinol. Arch. Int. Pharmacodyn. Ther. 1978, 233, 76-81. [PubMed]

45. Karniol, I.G.; Carlini, E.A. Comparative Studies in Man and in Laboratory Animals on $\Delta^{8}$-and $\Delta^{9}$-trans-Tetrahydrocannabinol. Pharmacology 1973, 9, 115-126. [CrossRef] [PubMed]

46. Karniol, I.G.; Shirakawa, I.; Takahashi, R.N.; Knobel, E.; Musty, R.E. Effects of delta9-tetrahydrocannabinol and cannabinol in man. Pharmacology 1975, 13, 502-512. [CrossRef] [PubMed]

47. Zimmer, B.D.; Bickel, P.; Dittrich, A. Changes of simple somatic parameters by delta-9-trans-tetrahydrocannabinol (delta-9-THC) in a double-blind-study. Short communication. Arzneimittelforschung 1976, 26, 1614-1616. [PubMed]

48. Haney, M. Opioid antagonism of cannabinoid effects: Differences between marijuana smokers and nonmarijuana smokers. Neuropsychopharmacology 2007, 32, 1391-1403. [CrossRef] [PubMed] 
49. Klooker, T.K.; Leliefeld, K.E.; Van Den Wijngaard, R.M.; Boeckxstaens, G.E. The cannabinoid receptor agonist delta-9-tetrahydrocannabinol does not affect visceral sensitivity to rectal distension in healthy volunteers and IBS patients. Neurogastroenterol. Motil. 2011, 23, 30-35. [CrossRef] [PubMed]

50. Lake, K.D.; Compton, D.R.; Varga, K.; Martin, B.R.; Kunos, G. Cannabinoid-induced hypotension and bradycardia in rats mediated by CB1-like cannabinoid receptors. J. Pharmacol. Exp. Ther. 1997, 281, 1030-1037. [PubMed]

51. Strougo, A.; Zuurman, L.; Roy, C.; Pinquier, J.L.; van Gerven, J.M.; Cohen, A.F.; Schoemaker, R.C. Modelling of the concentration-Effect relationship of THC on central nervous system parameters and heart rate-Insight into its mechanisms of action and a tool for clinical research and development of cannabinoids. J. Psychopharmacol. 2008, 22, 717-726. [CrossRef] [PubMed]

52. Schwope, D.M.; Bosker, W.M.; Ramaekers, J.G.; Gorelick, D.A.; Huestis, M.A. Psychomotor performance, subjective and physiological effects and whole blood Delta(9)-tetrahydrocannabinol concentrations in heavy, chronic cannabis smokers following acute smoked cannabis. J. Anal. Toxicol. 2012, 36, 405-412. [CrossRef] [PubMed]

53. Mathew, R.J.; Wilson, W.H.; Humphreys, D.; Lowe, J.V.; Wiethe, K.E. Middle cerebral artery velocity during upright posture after marijuana smoking. Acta Psychiatr. Scand. 1992, 86, 173-178. [CrossRef] [PubMed]

54. Mathew, R.J.; Wilson, W.H.; Humphreys, D.F.; Lowe, J.V.; Wiethe, K.E. Changes in middle cerebral artery velocity after marijuana. Biol. Psychiatry 1992, 32, 164-169. [CrossRef]

55. Klumpers, L.E.; Roy, C.; Ferron, G.; Turpault, S.; Poitiers, F.; Pinquier, J.L.; van Hasselt, J.G.; Zuurman, L.; Erwich, F.A.; van Gerven, J.M. Surinabant, a selective cannabinoid receptor type 1 antagonist, inhibits Delta9-tetrahydrocannabinol-induced central nervous system and heart rate effects in humans. Br. J. Clin. Pharmacol. 2013, 76, 65-77. [CrossRef] [PubMed]

56. Bhattacharyya, S.; Morrison, P.D.; Fusar-Poli, P.; Martin-Santos, R.; Borgwardt, S.; Winton-Brown, T.; Nosarti, C.; CM, O.C.; Seal, M.; Allen, P.; et al. Opposite effects of delta-9-tetrahydrocannabinol and cannabidiol on human brain function and psychopathology. Neuropsychopharmacology 2010, 35, 764-774. [CrossRef] [PubMed]

57. Niesink, R.J.; van Laar, M.W. Does Cannabidiol Protect Against Adverse Psychological Effects of THC? Front. Psychiatry 2013, 4, 130. [CrossRef] [PubMed]

58. Karniol, I.G.; Shirakawa, I.; Kasinski, N.; Pfeferman, A.; Carlini, E.A. Cannabidiol interferes with the effects of delta 9-tetrahydrocannabinol in man. Eur. J. Pharmacol. 1974, 28, 172-177. [CrossRef]

59. Stroke Therapy Academic Industry Roundtable. Recommendations for standards regarding preclinical neuroprotective and restorative drug development. Stroke 1999, 30, 2752-2758.

60. England, T.J.; Hind, W.H.; Rasid, N.A.; O'Sullivan, S.E. Cannabinoids in experimental stroke: A systematic review and meta-analysis. J. Cereb. Blood Flow Metab. 2015, 35, 348-358. [CrossRef] [PubMed]

61. Sultan, S.R.; Millar, S.A.; England, T.J.; O'Sullivan, S.E. A Systematic Review and Meta-Analysis of the Haemodynamic Effects of Cannabidiol. Front. Pharmacol. 2017, 8, 81. [CrossRef] [PubMed]

62. Higgins, J.P.; Altman, D.G.; Gotzsche, P.C.; Juni, P.; Moher, D.; Oxman, A.D.; Savovic, J.; Schulz, K.F.; Weeks, L.; Sterne, J.A.; et al. The Cochrane Collaboration's tool for assessing risk of bias in randomised trials. BMJ 2011, 343, 889-893. [CrossRef] [PubMed]

63. Neukirchen, M.; Kienbaum, P. Sympathetic nervous system: Evaluation and importance for clinical general anesthesia. Anesthesiology 2008, 109, 1113-1131. [CrossRef] [PubMed]

64. Egger, M.; Davey Smith, G.; Schneider, M.; Minder, C. Bias in meta-analysis detected by a simple, graphical test. BMJ 1997, 315, 629-634. [CrossRef] [PubMed]

(C) 2018 by the authors. Licensee MDPI, Basel, Switzerland. This article is an open access article distributed under the terms and conditions of the Creative Commons Attribution (CC BY) license (http:/ / creativecommons.org/licenses/by/4.0/). 